\title{
Quantifying sources of black carbon in western North America using observationally based analysis and an emission tagging technique in the Community Atmosphere Model
}

\author{
R. Zhang ${ }^{1,2,5,6}$, H. Wang ${ }^{2}$, D. A. Hegg ${ }^{3}$, Y. Qian ${ }^{2}$, S. J. Doherty ${ }^{4}$, C. Dang ${ }^{3}$, P.-L. Ma ${ }^{2}$, P. J. Rasch ${ }^{2}$, and Q. Fu ${ }^{1,3}$ \\ ${ }^{1}$ Key Laboratory for Semi-Arid Climate Change of the Ministry of Education, College of Atmospheric Sciences, \\ Lanzhou University, Lanzhou, 730000, Gansu, China \\ ${ }^{2}$ Atmospheric Sciences and Global Change Division, Pacific Northwest National Laboratory (PNNL), \\ Richland, WA 99352, USA \\ ${ }^{3}$ Department of Atmospheric Sciences, Box 351640, University of Washington, Seattle, WA 98195, USA \\ ${ }^{4}$ Joint Institute for the Study of Atmosphere and Ocean, 3737 Brooklyn Ave NE, Seattle, WA 98195, USA \\ ${ }^{5}$ Institute for Climate and Global Change Research \& School of Atmospheric Sciences, Nanjing University, \\ Nanjing, 210023, China \\ ${ }^{6}$ Collaborative Innovation Center of Climate Change, Jiangsu Province, Nanjing, 210023, China
}

Correspondence to: H. Wang (hailong.wang@pnnl.gov) and R. Zhang (rdzhang@nju.edu.cn)

Received: 21 March 2015 - Published in Atmos. Chem. Phys. Discuss.: 4 May 2015

Revised: 19 October 2015 - Accepted: 5 November 2015 - Published: 18 November 2015

\begin{abstract}
The Community Atmosphere Model (CAM5), equipped with a technique to tag black carbon (BC) emissions by source regions and types, has been employed to establish source-receptor relationships for atmospheric BC and its deposition to snow over western North America. The CAM5 simulation was conducted with meteorological fields constrained by reanalysis for year 2013 when measurements of $\mathrm{BC}$ in both near-surface air and snow are available for model evaluation. We find that CAM5 has a significant low bias in predicted mixing ratios of $\mathrm{BC}$ in snow but only a small low bias in predicted atmospheric concentrations over northwestern USA and western Canada. Even with a strong low bias in snow mixing ratios, radiative transfer calculations show that the BC-in-snow darkening effect is substantially larger than the $\mathrm{BC}$ dimming effect at the surface by atmospheric BC. Local sources contribute more to near-surface atmospheric $\mathrm{BC}$ and to deposition than distant sources, while the latter are more important in the middle and upper troposphere where wet removal is relatively weak. Fossil fuel (FF) is the dominant source type for total column BC burden over the two regions. FF is also the dominant local source type for BC column burden, deposition, and near-surface BC, while for all distant source regions combined the contribution
\end{abstract}

of biomass/biofuel (BB) is larger than FF. An observationally based positive matrix factorization (PMF) analysis of the snow-impurity chemistry is conducted to quantitatively evaluate the CAM5 BC source-type attribution. While CAM5 is qualitatively consistent with the PMF analysis with respect to partitioning of $\mathrm{BC}$ originating from $\mathrm{BB}$ and $\mathrm{FF}$ emissions, it significantly underestimates the relative contribution of $\mathrm{BB}$. In addition to a possible low bias in BB emissions used in the simulation, the model is likely missing a significant source of snow darkening from local soil found in the observations.

\section{Introduction}

Black carbon (BC) is the most light-absorbing component of anthropogenic aerosols, and it has been assessed to be responsible for a significant fraction of the climate warming in the Northern Hemisphere (Bond et al., 2013). BCcontaining particles impact the radiative balance of the Earthatmosphere system in several ways, including their "dimming effect" of reducing the amount of radiation reaching the surface, heating the atmosphere by absorbing radiation, and a darkening effect when incorporated in snow/ice at the 
surface, thereby increasing absorbed solar radiation (Flanner et al., 2007, 2009). The latter effect is of special interest due to the strong positive feedbacks it can trigger (e.g., Hansen and Nazarenko, 2004; Flanner et al., 2007; Bond et al., 2013). Largely because of this latter effect, BC may play a key role in causing climate change in the snow- and icecovered regions of the globe, which have undergone accelerated change in recent decades (Lubin and Vogelmann, 2006; Levis et al., 2007; IPCC, 2013). There have been numerous studies, both observational and modeling, attempting to highlight and understand the role of $\mathrm{BC}$ in accelerating changes in the cryosphere (e.g., Warren and Wiscombe, 1980; Clarke and Noone, 1985; Hansen and Nazarenko, 2004; Jacobson, 2004; Flanner et al., 2007, 2009; Ming et al., 2008; Xu et al., 2009; Koch et al., 2009; Doherty et al., 2010, 2013; Qian et al., 2011, 2015; Huang et al., 2011; Ye et al., 2012; Wang et al., 2015). However, with a few notable exceptions, the focus of these studies has been either in the polar regions or sharply circumscribed mid-latitude mountainous regions. Some recent studies (e.g., Flanner et al., 2009; Shindell and Faluvegi, 2009; Bond et al., 2013) have pointed out that the climatic effect of BC might be greater at mid-latitudes, a relatively understudied region, from the standpoint of global mean forcing.

An important aspect of the BC-climate connection is the source attribution of BC in the Earth system. Such attribution is important for the formulation of mitigation strategies, a particularly acute issue for $\mathrm{BC}$ since its relatively short lifetime holds promise for mitigation of near-term climate warming. In addition, the global $\mathrm{BC}$ forcing estimate is very uncertain mostly because of large uncertainties in BC emissions (e.g., Bond et al., 2013). Observational and modeling source-attribution studies focusing on specific receptor regions are useful for identifying biases in emissions. Previous source attribution studies have primarily focused on sources of BC to the Arctic (e.g., Law and Stohl, 2007; Shindell et al., 2008; Hirdman et al., 2010a, b; Huang et al., 2010; Jacobson, 2010; Hegg et al., 2009, 2010; Stohl, 2006; Sharma et al., 2006, 2013; Sand et al., 2013; Wang et al., 2014), the Antarctic (e.g., Graf et al., 2010), or various mountain regions (Fagerli et al., 2007; Kopacz et al., 2011; Lu et al., 2012; Zhang et al., 2015; Wang et al., 2015). A number of studies have also suggested the importance of long-range transport of aerosols to North America (e.g., Jaffe et al., 1999; VanCuren, 2003; Park et al., 2005; Heald et al., 2006; Chin et al., 2007; Hadley et al., 2007; Eguchi et al., 2009; Clarke and Kapustin, 2010; Fischer et al., 2010; Yu et al., 2012, 2013). A few of these studies assessed transport of BC to North America from various remote source regions using numerical models. For example, Hadley et al. (2007) found that long-range transport from Asia was a major source of $\mathrm{BC}$ in the upper atmosphere over North America.

Recently, Wang et al. (2014) introduced an explicit aerosol tagging technique to a global aerosol-climate model to produce a detailed characterization of the fate of $\mathrm{BC}$ in receptor regions of interest emitted from various geographical source regions. Compared to other widely used approaches (e.g., the emissions perturbation approach) that have been previously employed to establish global aerosol source-receptor relationships, the tagging approach neither assumes a linear response to perturbations to get fractional contribution of different sources nor requires additional simulations for each source perturbation. Thus we believe the tagging technique is more computationally efficient and gives more accurate results. Zhang et al. (2015) extended the Wang et al. (2014) modeling tool so it tags source types/sectors in addition to source regions, and they conducted a BC source attribution analysis over the Himalayas and Tibetan Plateau. This modeling framework provides a powerful tool for looking at source attribution of $\mathrm{BC}$ in North America, an understudied mid-latitude region for $\mathrm{BC}$ in snow.

A key facet of employing any model such as that of Zhang et al. (2015) is an assessment of how well it actually reproduces observed values. Atmospheric observational data from the Interagency Monitoring of Protected Visual Environments (IMPROVE) long-term surface monitoring network permit an assessment of model predictions of nearsurface atmospheric concentrations of BC. Observations of $\mathrm{BC}$ in snow in the Arctic and northern China have been used to evaluate models in several previous studies (e.g., Flanner et al., 2007; Skeie et al., 2011; Wang et al., 2011; Lee et al., 2013; Jiao et al., 2014; Qian et al., 2014; Zhao et al., 2014). A recent study by Doherty et al. (2014) presented a large-area survey of observed BC concentrations in snow in western North America (Fig. S1 in the Supplement), affording an opportunity to make such an assessment for model predictions of $\mathrm{BC}$ in snow. For the first time, we use their measurements of BC in snow over North America to evaluate our global aerosol-climate model in terms of the amount and sources of BC in snow. The Doherty et al. (2014) study included a positive matrix factorization (PMF) source attribution analysis of $\mathrm{BC}$ in snow, making feasible an additional assessment of the source attribution of BC in snow in the enhanced Community Atmosphere Model version 5 (CAM5) model. Here we assess the CAM5 results against these observations and analyses for two receptor areas defined by the western North American region for which the Doherty et al. (2014) data are available.

Additionally, we present radiative transfer calculations in the atmosphere and snow with the evaluated model to assess the impact of the modeled $\mathrm{BC}$ as well as dust on the radiative balance for the studied region. This facilitates a comparison of the radiative forcing between this region and other midlatitude or high-latitude regions. 


\section{Methods}

\subsection{Observations}

Monthly-mean near-surface atmospheric BC concentrations for January, February, and March of 2013 used in this study are from IMPROVE non-urban background sites within the United States (Malm et al., 1994). Fine particles $\left(\mathrm{PM}_{2.5}\right.$, particles with aerodynamic diameters $<2.5 \mu \mathrm{m}$ ) are captured on filters, which are weighed and then subjected to BC concentration analysis using the thermal-optical measurement technique in a laboratory (Chow et al., 1993, 2007).

While previous observation/model comparisons of $\mathrm{BC}$ in snow have typically compared $\mathrm{BC}$ mixing ratios in the surface snow, here we compare the average snow column $\mathrm{BC}$ mixing ratio (calculated as the sum of all $\mathrm{BC}$ in the snow column divided by the column equivalent water mass, hereafter BCC) over a specified period of time. This is likely a better metric for model comparison than the $\mathrm{BC}$ concentration in the top snow layer only, since surface snow mixing ratios at a given point in time can be strongly affected by, e.g., how recently new snow fell, accurate representation of BC mixing ratios in the most recent snowfall, and other processes that can vary on the timescale of days. In particular, melting of surface snow can strongly enhance surface snow mixing ratios but melting followed by percolation and refreezing redistributes $\mathrm{BC}$ particles within the snow column, resulting in no change to the total BC mass in the snow column. Indeed, Doherty et al. (2014) found that BCC is more regionally consistent than BC concentrations in top snow layer. Further, they showed that while there were vertical variations in the mixing ratio of $\mathrm{BC}$ in snow at their study sites there is no consistent vertical gradient. This is also the case in the model (Table S1 in the Supplement) consistent with the fact that BC emissions during the cold season do not have strong temporal gradient. Hence, in this study, we use the BCC data from Table 6 of Doherty et al. (2014) to evaluate our model.

The BCC estimates by Doherty et al. (2014) are based on samples of seasonal snow collected January through March 2013 at 67 sites in northwestern and northcentral USA and Canada. Snow BC mixing ratios are estimated based on an optical measurement of spectrally resolved light absorption by all particles in the snow, using an ISSW (integrating sphere/integrating sandwich) spectrophotometer (Grenfell et al., 2011). Absorption is apportioned to $\mathrm{BC}$ and non- $\mathrm{BC}$ particulate components using the measured absorption Ångström exponent $450-600 \mathrm{~nm}$ along with assumed absorption Angström exponents of the BC and non$\mathrm{BC}$ components. Note that the absorption Ångström exponent is the slope of the logarithm of absorption versus the logarithm of wavelength. Absorption attributed to $\mathrm{BC}$ is then converted to a $\mathrm{BC}$ mass mixing ratio using a set of calibration standards with weighed amounts of synthetic BC. Full details of the analysis are given by Grenfell et al. (2011) and Doherty et al. (2014). Of relevance here is that this is not a direct measure of BC but an estimate of mass based on measured absorption and the assumed optical properties of these absorbing components.

\subsection{Model description and experimental design}

An explicit BC source tagging capability was developed in the CAM5 by Wang et al. (2014), and they applied it to establish source-receptor relationships for BC in the Arctic and quantify source contributions from a few major geographical regions. Zhang et al. (2015) extended this tool to quantifying sources of BC in the Himalayas and Tibetan Plateau originating from biomass and biofuel (BB) and fossil-fuel (FF) sectors in various regions. In this study, we use CAM5 with this explicit $\mathrm{BC}$ tagging technique, including a recently improved representation of convective transport and wet scavenging of aerosols (H. Wang et al., 2013). We conduct a CAM5 simulation at a horizontal resolution of $1.9^{\circ} \times 2.5^{\circ}$ and 56 vertical levels in the specified dynamics mode (Ma et al., 2013), in which model meteorology (e.g., wind, temperature, surface pressure, surface stress, and surface fluxes) are constrained to agree with the NASA Modern-Era Retrospective Analysis for Research and Applications (MERRA) 6hourly reanalysis (Rienecker et al., 2011), while atmospheric constituents such as water vapor, clouds, and aerosols are allowed to evolve according to their prognostic equations in the model. Although land surface processes including those involving $\mathrm{BC}$ in snow are not directly nudged to observations, the constrained meteorological fields should make modeled precipitation and $\mathrm{BC}$ deposition more accurate. Monthlymean model fields for January to March 2013 are used for the comparison to observations in the large-area survey of $\mathrm{BC}$ in snow in western North America (Doherty et al., 2014) and in the comparison to the IMPROVE surface network measurements, and they are used to establish source-receptor relationships and quantify $\mathrm{BC}$ radiative forcing.

Accurate $\mathrm{BC}$ emissions are critical to accurate modeled distributions of $\mathrm{BC}$ in the atmosphere and snow, but $\mathrm{BC}$ emissions are highly uncertain (e.g., Bond et al., 2013). Instead of using the Intergovernmental Panel on Climate Change (IPCC) AR5 present-day (year 2000) BC inventory (e.g., Lamarque et al., 2010), we compile a new BC emission data set of year 2010 for our simulation. The 2010 BC emission data set consists of three parts: (1) the annually constant total BC emissions over land surfaces, obtained from the ECLIPSE (Evaluating the Climate and Air Quality Impacts of Short-Lived Pollutants) V4a data set (Stohl et al., 2015), which was developed within the framework of the ECLIPSE European project (http://eclipse.nilu.no) using the Greenhouse gas and Air pollution Interactions and Synergies (GAINS) model (Amann et al., 2011), including BC emissions from gas flaring (Stohl et al., 2013); (2) the 2010 annually constant BC shipping emissions from the IPCC RCP6 (Representative Concentration Pathways); and (3) the 2010 seasonally varying biomass burning (BB) BC emissions 
from the Global Fire Emission Database (GFED) version 3 (van der Werf et al., 2010). Emission data sets for all other aerosol species are obtained from the IPCC AR5 emission inventories (Lamarque et al., 2010).

To prepare $\mathrm{BC}$ emissions for the source-type tagging in the CAM5 simulation, we first divide the total ECLIPSE $\mathrm{BC}$ emissions over land surface into two types, fossil fuel, and biofuel, using the ratio of biofuel to the total (biofuel plus fossil fuel) in each model grid provided by Dentener et al. (2006). In order to make the model source categories directly comparable to those given by the PMF analysis using the observational data, we then combine the GFED biomass burning emissions and ECLIPSE surface biofuel emissions to form the $\mathrm{BB}$ emission sector (biofuel and biomass). This is because, as discussed below, the PMF is unable to distinguish open burning (fires) from biofuel burning. The IPCC RCP6 shipping emissions and ECLIPSE surface fossil-fuel emissions are also combined to form the FF emission sector (fossil fuel). Figure $\mathrm{S} 2$ shows the geographical distributions of JFM (January, February, and March) mean BB and FF BC emission rate for year 2010 data set we compiled.

Following the division of source/receptor regions in Work Plan (WP 2.1) of the Task Force on Hemispheric Transport of Air Pollution (http://iek8wikis.iek.fz-juelich.de/ HTAPWiki/WP2.1), we define 15 geographical source regions (Fig. 1a) for this study, including ARC (Arctic), WCA (western Canada and Alaska), ECA (eastern Canada), LAM (Latin America), NWU (northwestern USA), NEU (northeastern USA), SWU (southwestern USA), SEU (southeastern USA), EAS (East Asia), SAS (South Asia), SEA (Southeast Asia), ERCA (Europe, Russia, and Central Asia), AFME (Africa and Middle East), PAN (Pacific, Australia, and New Zealand), and ROW (rest of the world).

Figure $1 \mathrm{~b}$ summarizes the fractional contributions to global total $\mathrm{BC}$ emissions by different source regions and sectors. The JFM mean global total $\mathrm{BC}$ emission rate is $7.69 \mathrm{Tg} \mathrm{yr}^{-1}$ with $53.5 \%$ (sum of the red bars) from the BB sector and $46.5 \%$ (sum of the blue bars) from the FF sector. Emissions from source regions in North America (i.e., WCA, ECA, NWU, NEU, SWU, and SEU) are quite low compared to the emissions from the major source regions in Asia, Europe, and Africa.

\subsection{Metrics}

Here we define two metrics, following Lee et al. (2013), to quantify the deviation of the simulated values from the observations.

Log-mean normalized bias (LMNB) is defined as

$\mathrm{LMNB}=\frac{\sum_{i=1}^{N} \log _{10}\left(\frac{C_{\mathrm{mod}}^{i}}{C_{\mathrm{obs}}^{i}}\right)}{N}$.
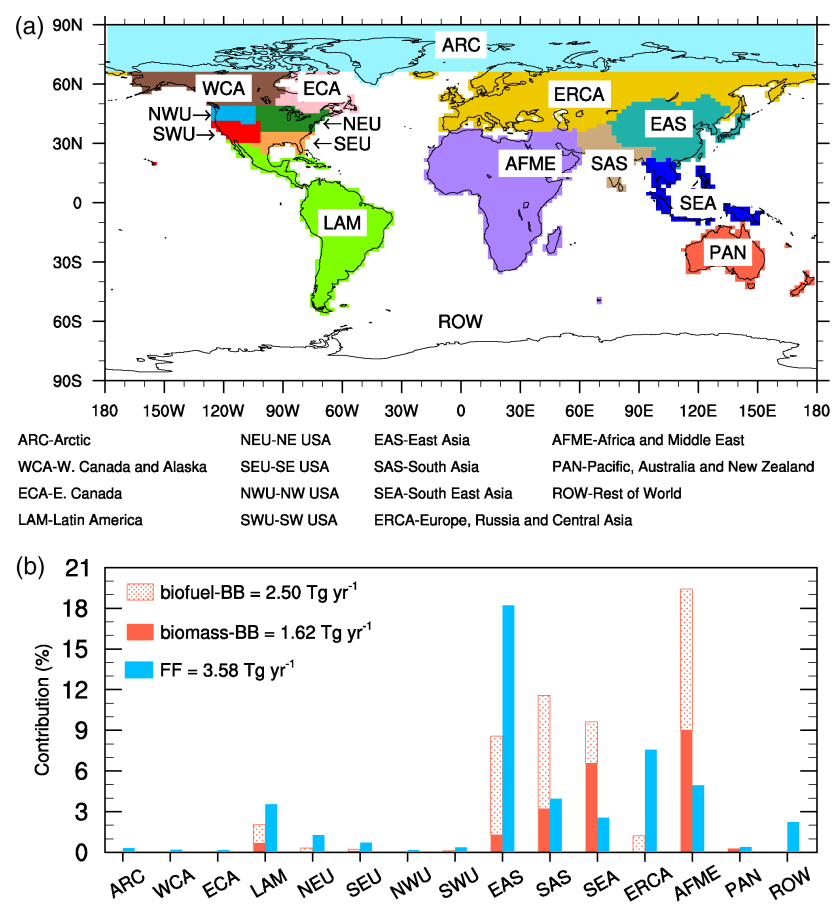

Figure 1. (a) Tagged source regions and (b) the contributions (\%) to the global mean BC emissions ( $7.69 \mathrm{Tg} \mathrm{yr}^{-1}$ ) for January, February and March from the individual source regions (marked on the horizontal axis) and sectors (FF in blue, biomass-BB in solid red, and biofuel-BB in dotted red).

$\mathrm{LMNE}=\frac{\sum_{i=1}^{N}\left|\log _{10}\left(\frac{C_{\mathrm{mod}}^{i}}{C_{\mathrm{obs}}^{i}}\right)\right|}{N}$.

$N$ is the total number of data points in a given region for model evaluation. At each point $i$, the modeled value $\left(C_{\text {mod }}^{i}\right)$ represents the grid mean, while the observed value $\left(C_{\mathrm{obs}}^{i}\right)$ is the average of all point measurements taken within the model grid cell.

We also define metrics to quantify fractional contribution $\left(C_{i}^{\mathrm{BB}}\right.$ and $\left.C_{i}^{\mathrm{FF}}\right)$ and emission source efficiency $\left(S_{i}^{\mathrm{BB}}\right.$ and $\left.S_{i}^{\mathrm{FF}}\right)$, following Zhang et al. (2015), as follows:

$$
C_{i}^{\mathrm{BB}}=\frac{A_{i}^{\mathrm{BB}}}{\sum_{i=1}^{N}\left(A_{i}^{\mathrm{BB}}+A_{i}^{\mathrm{FF}}\right)} \quad C_{i}^{\mathrm{FF}}=\frac{A_{i}^{\mathrm{FF}}}{\sum_{i=1}^{N}\left(A_{i}^{\mathrm{BB}}+A_{i}^{\mathrm{FF}}\right)},
$$

where $C_{i}^{\mathrm{BB}}$ and $C_{i}^{\mathrm{FF}}$ are fractional contributions of $\mathrm{BB}$ and FF emissions, respectively, originating from the source region $i$ to a $\mathrm{BC}$ property $A_{i}^{\mathrm{BB}}$ and $A_{i}^{\mathrm{FF}}$ (e.g., mass mixing ratio, column burden, or deposition flux) in a specified receptor region; and

Log-mean normalized error (LMNE) is defined as 


$$
S_{i}^{\mathrm{BB}}=\frac{C_{i}^{\mathrm{BB}}}{\left[\frac{E_{i}^{\mathrm{BB}}}{\sum_{i=1}^{N}\left(E_{i}^{\mathrm{BB}}+E_{i}^{\mathrm{FF}}\right)}\right]} \quad S_{i}^{\mathrm{FF}}=\frac{C_{i}^{\mathrm{FF}}}{\left[\frac{E_{i}^{\mathrm{FF}}}{\sum_{i=1}^{N}\left(E_{i}^{\mathrm{BB}}+E_{i}^{\mathrm{FF}}\right)}\right]}
$$

where $S_{i}^{\mathrm{BB}}$ and $S_{i}^{\mathrm{FF}}$ are the source efficiencies of $\mathrm{BB}$ and $\mathrm{FF}$ emissions, respectively, originating from the source region $i$, in changing $\mathrm{BC}$ in a specified receptor region. $E_{i}^{\mathrm{BB}}$ and $E_{i}^{\mathrm{FF}}$ are the $\mathrm{BB}$ and $\mathrm{FF}$ emission rates, respectively, in the source region $i$. The summation $\sum_{i=1}^{N}\left(E_{i}^{\mathrm{BB}}+E_{i}^{\mathrm{FF}}\right)$ represents the global total emission rate from all source regions ( $N=15$ in this study). Thus the denominator terms are the corresponding contribution of $\mathrm{BB}$ or FF emissions in source region $i$ to the global total $\mathrm{BC}$ emissions (Fig. 1b), and the efficiencies $S_{i}^{\mathrm{BB}}$ and $S_{i}^{\mathrm{FF}}$ characterize the sensitivity of BC properties in a specified receptor region to per-unit BB and FF emissions, respectively, in source region $i$.

\subsection{Data preparation for source attribution}

In addition to $\mathrm{BC}$ concentrations in snow, Doherty et al. (2014) also provide a PMF analysis of the sources of light absorption by all particulates in the snow. In brief, the PMF analysis determined the set of orthogonal factors, each with an associated chemical "fingerprint", that are associated with variations in light absorption by all particulates in snow. Each of the factors are then associated with specific source types (e.g., biomass burning, fossil-fuel burning, soil, mineral dust) based on their chemical fingerprints. The chemical markers from open biomass burning (e.g., forest fires) and biofuel burning (e.g., woodsmoke from fireplaces and wood stoves) are quite similar, so biomass and biofuel sources cannot be distinguished in the PMF; both sources would be included in the factor identified as "biomass burning". In order to do a comparison to CAM5, which tracks the sources of $\mathrm{BC}$ only, rather than all light-absorbing species to snow, we re-ran the PMF analysis so it determined the sources that contribute to variations in snow $\mathrm{BC}$ only (i.e., $C_{\mathrm{BC}}^{\mathrm{est}}$ in Doherty et al., 2014). This PMF analysis of sources of BC in snow (Fig. S3) shows a similar, though not identical, source attribution as that for all light-absorbing particulates in snow (given in Doherty et al., 2014). For both, the main source sectors are pollution (likely mainly fossil-fuel combustion), soil, and biomass/biofuel burning. These three categories account for almost all of the light absorption by BC and other particles in the snow samples. The fractional contribution of the fossil-fuel/pollution source is higher for BC (Fig. S3) than for total particulate absorption (Doherty et al., 2014), and the fractional contribution by the soil factor is lower for BC than for total particulate absorption. The issue of the nature of a $\mathrm{BC}$ component associated with soil, which is not intuitively obvious, is discussed below.
The estimated snow BC concentration used in the PMF analysis and the fraction of absorption due to the biomass burning, pollution/fossil-fuel and soil sources $\left(F_{\mathrm{BB}}, F_{\mathrm{FF}}\right.$, and $\left.F_{\text {SOIL }}\right)$ from the PMF analysis are given in the Table $\mathrm{S} 2$. The $\mathrm{PMF}$ analysis allows some factors to contribute negative fractions to absorption, which is of course unphysical. To rationalize the data for comparison with CAM5, we first set all negative fractions $F_{\mathrm{BB}}, F_{\mathrm{FF}}$, and $F_{\mathrm{SOIL}}$ to 0 and then scale the remaining fractions so that they sum to 1.0 , yielding adjusted values $f_{\mathrm{BB}}, f_{\mathrm{FF}}$, and $f_{\text {soil }}$.

We next calculate average fractional contributions by the $\mathrm{BB}$ and FF sources from the PMF analysis for each of the snow samples sites falling within a given model grid box, using Eq. (A1) in the Appendix. It is important to note that the sum of BB and FF contributions does not necessarily equal to $100 \%$. This is, of course, because of the soil source in the PMF model, a source of BC not present in CAM5. This renders the comparison between the model (i.e., CAM5) and observed (i.e., PMF) sources of BC imperfect, an issue that will be discussed further below. The CAM5 JFM mean fractional contributions for the BB and FF sectors in each model grid box, where observational/PMF data are available, are calculated using Eq. (A2). Note that the sum of BB and FF contributions equals to $100 \%$.

Based on the above procedures, we calculate the regional average of fractional contributions from the BB and FF sectors from the PMF analysis and from the CAM5 simulation using Eqs. (A3) and (A4), respectively. In principle, another fraction corresponding to the soil contribution should also be present in Eq. (A3) for the PMF analysis. By excluding this fraction, we are essentially renormalizing our fractional contributions such that $\overline{\mathrm{BB}_{\mathrm{obs}}}$ and $\overline{\mathrm{FF}_{\mathrm{obs}}}$ now represent the fractions of direct combustion emissions (fossil fuel and biomass/biofuel) that can be attributed to the BB and FF sectors. This renders these fractions equivalent to those generated by CAM5 via Eq. (A4).

\section{Results and discussion}

\subsection{Near-surface atmospheric BC concentrations}

There are 42 non-urban IMPROVE observation sites available in the northwest of the USA (Fig. S4). For comparison with model results, measurements at sites located in the same model grid box are averaged first. As a result, we obtain 30 model/observation comparison pairs. The following analysis is based on the JFM mean modeled and observed values for these 30 comparison pairs.

Figure 2 a shows the scatter plot of simulated versus observed JFM mean near-surface BC concentrations. About $57 \%$ of the ratios fall within a factor of 2 . The linear correlation coefficient $(R)$ is 0.5 . The statistical significance of $R$ is at $>99 \%$ confidence level ( $p=0.005, N=30)$. The LMNB and LMNE are calculated using Eqs. (1) and (2), re- 

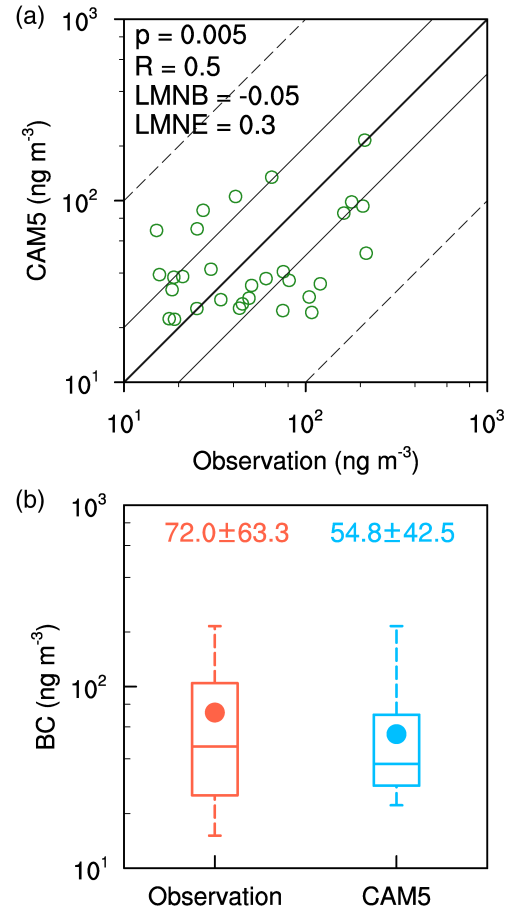

Figure 2. (a) Scatter plot of CAM5 simulated versus observed JFM mean near-surface atmospheric BC concentrations $\left(\mathrm{ng} \mathrm{m}^{-3}\right)$ in 2013 at the IMPROVE network sites. The observations are averages across sites falling into the same model grid box. The correlation coefficient $(R)$, the statistical significance of $R(p)$, the log-mean normalized bias (LMNB), and the log-mean normalized error (LMNE) are shown in numbers in the top-left corner; the $1: 1$ (thick solid), $2: 1$ (thin solid) and 10:1 (dashed) lines are also plotted for reference. (b) Box and whisker plot of observed (red color) and simulated (blue color) JFM mean of near-surface BC concentrations $\left(\mathrm{ng} \mathrm{m}^{-3}\right)$ for all comparison pairs. The 25th, 50th, and 75th percentiles are marked with a box, the mean value with a dot, and the minimum and maximum values with whiskers; the colored numbers give the mean and standard deviation for the observed (red) and modeled values (blue).

spectively. The CAM5 results over the 30 grid boxes have LMNB of -0.05 , which means that the model-predicted BC concentrations are smaller than observations by $11 \%(=1-$ $10^{-0.05}$ ) on average. The model error relative to the observations is, however, more substantial. The LMNE is 0.3 , which means that the model predictions are, on average, within a factor of $2\left(=10^{0.3}\right)$ of the observations. Figure $2 \mathrm{~b}$ shows statistics for the JFM near-surface BC concentrations for the IMPROVE observations and CAM5 results, respectively. The model moderately underpredicts mean and median BC concentrations, as expected. The maximum observed and modeled near-surface $\mathrm{BC}$ concentrations among the sites are close, but the modeled minimum and 25th percentile values are higher than observed values. The observed and modeled mean values ( $\pm \mathrm{SD}$ - standard deviation) are $72.0 \pm 63.3 \mathrm{ng} \mathrm{m}^{-3}$ and $54.8 \pm 42.5 \mathrm{ng} \mathrm{m}^{-3}$, respectively.
The strong spatial variation in $\mathrm{BC}$ over these sites, indicated by the high coefficient of variation (i.e., the ratio of the standard deviation to the mean - see also the spatial distributions of BC in Fig. S4), renders the comparison of these midlatitude observations with CAM5 (having a horizontal grid spacing of $1.9^{\circ} \times 2.5^{\circ}$ ) challenging. In this light, we consider the model-observational agreement within a factor of two quite reasonable.

\subsection{BC-in-snow cocentrations}

In addition to evaluation of $\mathrm{BC}$ in the atmosphere, we also evaluate the model performance with respect to $\mathrm{BC}$ in snow. Figure 3 shows a comparison between CAM5 predictions of $\mathrm{BCC}$ and the corresponding observations of BCC from the 49 sampling sites given in Table 6 of Doherty et al. (2014). We obtain 36 observation/model comparison pairs by averaging measurements made at all sites located in the same model grid box. This results in 20 comparison pairs in northwestern USA and 16 in western Canada (Fig. 3d; BCC concentrations for individual pairs are summarized in Table S3). Modeled BCC does not differ appreciably between January, February, and March for the grid boxes where we made comparisons, so we use the mean BCC across all 3 months (JFM) in the comparison with the observation.

Figure $3 \mathrm{a}$ shows the scatter plot of the simulated JFM mean values compared to observed BCC over the 36 observation/model pairs. BCC is substantially lower in the modeled snowpack than in the observations. This model low bias in BCC is substantially larger than in near-surface atmospheric concentrations of BC (hereafter, referred to as BCS) discussed in the previous section. Indeed, the contrast in the model-observational bias of $\mathrm{BCC}$ as compared to the bias for BCS is quite interesting and suggestive of the sources of the bias in the BCC model-observational comparison. However, it is important to note here that we are not comparing $\mathrm{BCS}$ values with $\mathrm{BCC}$ values but rather comparing the model-observational biases of the two variables.

The linear correlation coefficient $(R)$ for the modeled versus observed BC mixing ratios in snow is 0.2 , significant only at the $70 \%$ level $(p=0.3, N=36)$. The CAM5 BCC has a LMNB (Eq. 1) of -0.2 which means that the modelpredicted BCC concentrations are lower than the observations by $37 \%\left(=1-10^{-0.2}\right)$ on average. The LMNE (Eq. 2) in the CAM5 BCC is 0.3 which means that the model predictions are, on average, within a factor of $2\left(=10^{0.3}\right)$ of the observations, though as noted above the correlation between the two is poor. The observed and modeled means $( \pm \mathrm{SD})$ for these $36 \mathrm{BCC}$ values are $32.7 \pm 24.5 \mathrm{ng} \mathrm{g}^{-1}$ and $19.1 \pm 11.5 \mathrm{ng} \mathrm{g}^{-1}$, respectively. As was the case with model comparisons for BCS, BCC has a large coefficient of variation (i.e., the ratio of the standard deviation to the mean), reflecting the strong spatial variation of $\mathrm{BCC}$ in this region (Fig. 3d). 

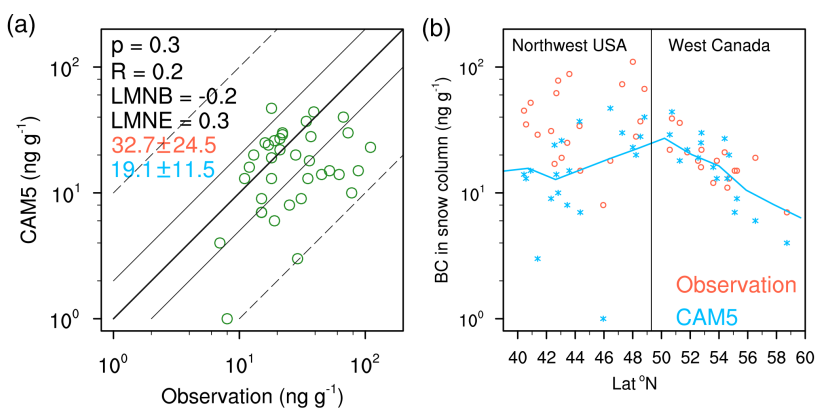

(c)

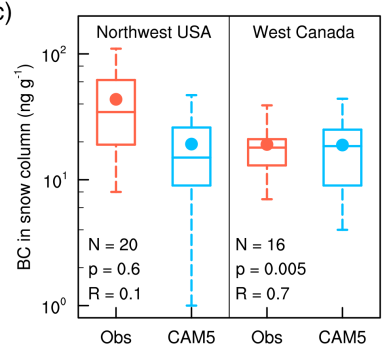

(d)

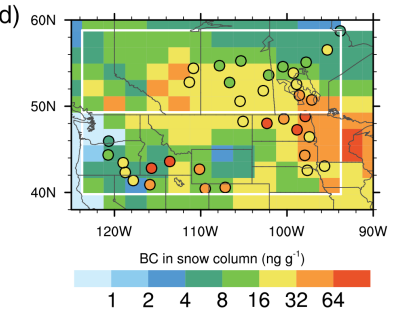

Figure 3. (a) Scatter plot of simulated versus observed BC concentrations ( $\mathrm{ng}^{-1}$ ) in the snow column (BCC). As in Fig. 2, $R, p$, LMNB, and LMNE are shown in numbers on the top-left corner; the color numbers show the mean and standard deviation for observations (red) and modeled values (blue). (b) Observed (red circle) and simulated (blue asterisk) BCC versus latitude for the 36 comparison pairs in northwestern USA and western Canada. The modeled values are the JFM mean. The blue line indicates the modeled JFM zonal-mean values over the longitude band $93.75-123.75^{\circ} \mathrm{W}$ (white outlines in panel d) for BCC. (c) Box and whisker plot of observed (red color) and simulated (blue color) BCC in the two regions. The 25th, 50th, and 75th percentiles are marked with a box, the mean value with a dot, and the minimum and maximum values with whiskers; the number of samples $(N), R$, and $p$ for each region are shown at the bottom. (d) Spatial distributions of modeled JFM mean BCC with the observed BCC (color circles with black outlines) superimposed. In (d) the observed values are averages across the sampling sites of Doherty et al. (2014), when more than one sampling site fell within a model grid box. The white boxes in (d) outline the two receptor regions, northwestern USA $\left(39.8-49.3^{\circ} \mathrm{N}, 93.75-\right.$ $\left.123.75^{\circ} \mathrm{W}\right)$ and western Canada $\left(49.3-58.8^{\circ} \mathrm{N}, 93.75-123.75^{\circ} \mathrm{W}\right)$.

Figure $3 \mathrm{~b}$ compares the simulated and observed BCC as a function of latitude. The modeled JFM zonal mean of BCC over the longitude range of $93.75-123.75^{\circ} \mathrm{W}$ (blue line in Fig. 3b) shows an increasing trend with latitude in the northwestern USA and a decreasing trend in western Canada. This trend is also seen in the observations in western Canada, but there is no trend in BCC with latitude in the northwestern USA. The model agrees well with the observations in Canada but has generally lower concentrations of BC in snow in the US (Fig. 3c). The observed values of BCC range between 8 and $110 \mathrm{ng} \mathrm{g}^{-1}$ in the northwestern USA with a mean of $44 \mathrm{ng} \mathrm{g}^{-1}$ and between 7 and $39 \mathrm{ng} \mathrm{g}^{-1}$ in western Canada with a mean of $19 \mathrm{ng} \mathrm{g}^{-1}$. The correlation coefficient between the observed and modeled BCC is low $(R=0.1)$

for the northwestern USA with negligible statistical significance $(p=0.6, N=20)$. However, the correlation coefficient $(R)$ is relatively high (0.7) for western Canada, significant at $>99 \%$ confidence level $(p=0.005, N=16)$. The good agreement between the model estimates and observations of BCC for western Canada argues against a systematic problem with model deposition processes.

Turning next to the regionally stratified LMNB and LMNE values, for the northwestern USA region, the LMNB and LMNE are -0.39 (59\% low bias) and 0.47 (a factor of 3), respectively, while for western Canada, LMNB and LMNE are -0.04 ( $9 \%$ low bias) and 0.17 (a factor of 1.5), respectively. Hence, for western Canada the model bias is essentially the same for the BCC as it is for the BCS (in northwestern USA). Turning next to the regionally stratified LMNB and LMNE values, for the northwestern USA region, the LMNB and LMNE are -0.39 (59\% low bias) and 0.47 (a factor of 3), respectively, while for western Canada, LMNB and LMNE are - 0.04 (9\% low bias) and 0.17 (a factor of 1.5), respectively. Hence, for western Canada the model bias is essentially the same for the BCC as it is for the BCS (in northwestern USA) while the model error is actually appreciably less. For northwestern USA, however, the LMNE is substantially worse for BCC than it was for BCS. Furthermore, most of this error is associated with a model low bias far larger that was the case for BCS. Note that the measurements of BCS and BCC are from different locations and are not necessarily representative of the whole model grid box, so the comparison of biases in BCS and BCC is not ideal but is nonetheless informative. Although BCC and BCS at a given location depend on different processes that occur on different timescales, averaging over the 3-month time period and/or across snow columns at the available sites should be sufficient to make the biases in BCS and BCC comparable. however, the LMNE is substantially worse for BCC than it was for BCS. Furthermore, most of this error is associated with a model low bias far larger that was the case for BCS. Note that the measurements of BCS and BCC are from different locations and are not necessarily representative of the whole model grid box, so the comparison of biases in $\mathrm{BCS}$ and $\mathrm{BCC}$ is not ideal but is nonetheless informative. Although BCC and BCS at a given location depend on different processes that occur on different timescales, averaging over the 3-month time period and/or across snow columns at the available sites should be sufficient to make the biases in BCS and BCC comparable.

The smaller error (LMNE) in BCC for western Canada than for BCS in the northwestern USA indicates the model might also be doing a better job of predicting BCS in western Canada than in the northwestern USA, but it is not possible to know this since all the BCS observations we have are from sites in the USA. For the northwestern USA sites the substantially larger low bias in BCC versus in BCS is quite interesting. A commonly invoked explanation for a low bias in model predictions of atmospheric BC has been flawed 

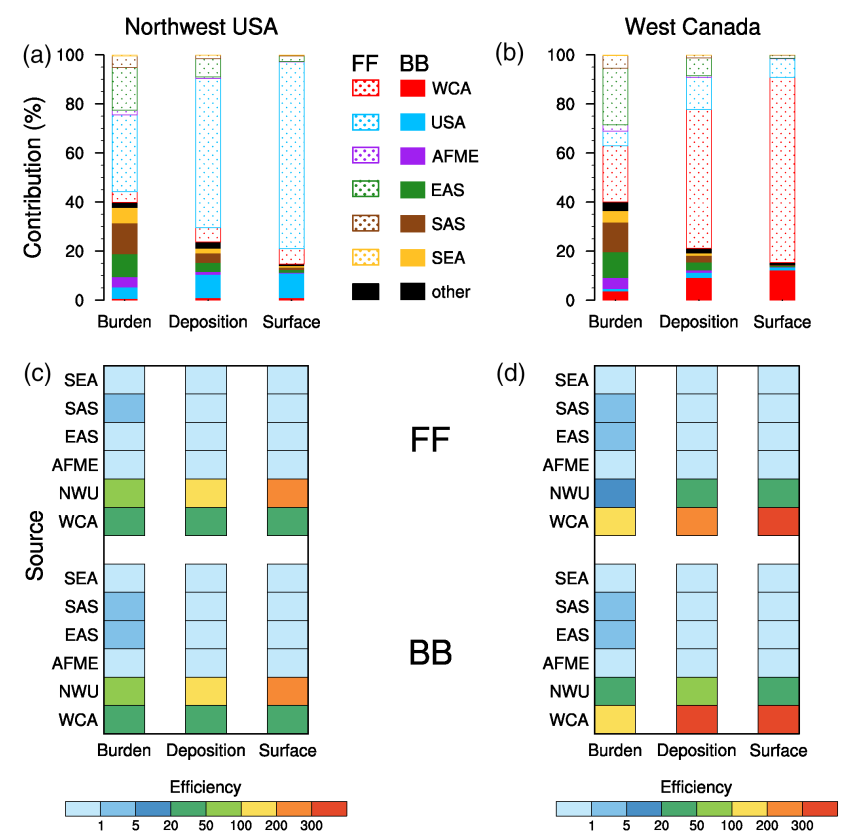

Figure 4. Fractional contributions to JFM mean BC total column burden, deposition and near-surface concentrations over (a) northwestern USA and (b) western Canada (as defined in Fig. 3d), from six major tagged source regions (colors) and sectors (solid color and stippled bar for BB and FF, respectively); the black bar in each column represents the combined contribution from all of the other tagged source regions and sectors. (c) and (d) show efficiency of FF (top) and BB (bottom) emissions from six major tagged source regions (marked on the $y$ axis) in changing JFM mean BC total column burden, deposition and near-surface concentrations over northwestern USA (c) and western Canada (d).

emissions inventories. For example, Mao et al. (2011) indicated that there is a large uncertainty in the emissions of $\mathrm{BC}$ from biomass burning in western North America. However, the larger low bias in BCC compared to BCS suggests that deficiencies in emissions inventories are not likely the primary explanation for the model underprediction of BCC in this instance, since a source-based bias should show up in both BCS and BCC (similar source attribution of BCS and BC deposition shown in Fig. 4), assuming the model representation of deposition/scavenging processes is not flawed. In fact, the small bias in model-predicted BCC in western Canada indicates that the model representation of $\mathrm{BC}$ deposition is less likely to be the primary cause of the large low bias in BCC in northwestern USA.

In addition to emissions or model processes errors, another possibility for the difference in modeled and observed BCC is a bias ${ }^{1}$ in the observational estimates. In a recent comparison, Schwarz et al. (2012) found that estimates of the

\footnotetext{
${ }^{1}$ For simplicity and consistency we use "model bias" below to describe the difference between model results and observations, although the measurements might have a significant bias or error.
}

mixing ratio of $\mathrm{BC}$ in snow using the ISSW (used in the Doherty et al. (2014) study to estimate BCC) were biased high by up to a factor of 3 when $\mathrm{BC}$ is mixed with dust. While this artifact could possibly explain a portion of the observed discrepancy between the model predictions and the observations, it is not fully consistent with the contrast in model-observational comparisons between the northwestern USA and western Canadian regions. Although there is significantly less dust in the Canadian samples (based on both ISSW analysis of $\mathrm{BC} /$ non-BC partitioning of absorption and the PMF analysis) than for northwestern USA, the amount of dust present at the western Canadian sites is still substantial: the PMF analysis suggests that $\sim 17 \%$ of the light absorption is associated with dust for the Canadian sites on average, and much more at some sites, whereas it is $\sim 36 \%$ at the US sites. Given this, we would expect to also find a model low bias in BCC for Canada on the order of half that in the northwestern US, e.g., LMNB of about -0.2 , rather than the actual near-zero bias $(\mathrm{LMNB}=-0.04)$. Hence, the relatively good model-observational agreement for the Canadian sites makes it unlikely that measurement bias in BCC is the sole source of the discrepancy between the CAM5 predications and the field observations.

Another possible cause of lower BCC in the model versus the observations is a missing source of $\mathrm{BC}$ to snow in the model. The sources of BC in CAM5 are biofuel burning, biomass burning, and fossil-fuel combustion. In the model, emissions of $\mathrm{BC}$ from these sources are incorporated in surface snow either in snowfall (wet deposition) or by settling directly to the surface snow (dry deposition). In contrast to this, the PMF analysis suggests that a significant source of $\mathrm{BC}$ in snow is soil. At first glance this seems counterintuitive, since soil itself does not produce BC. However, in mid-latitude regions the snow is often patchy and intermixed with large areas of exposed soil. This soil can mix with the snow mechanically (e.g., by livestock; X. Wang et al., 2013) or by winds, which loft the soil and deposit it to snow on scales of tens to hundreds of meters (Doherty et al., 2014). These exposed soil areas are subject to BC deposition throughout the year and likely accumulate a substantial reservoir of BC from a multitude of sources (e.g., Schmidt and Noack, 2000; Hegarty et al., 2011). This deposited $\mathrm{BC}$ is then subject to re-suspension via saltation and deposition on the surrounding snow, along with the soil. As mentioned above, the contribution of the soil/dust source to light absorption by snow impurities for the Canadian sites is $17 \pm 5 \%$. In contrast, for the US sites it is $36 \pm 4 \%$, consistent with the thinner and more variable snow cover in the US region (snow cover fraction derived from satellite measurements shown in Fig. S5). While the magnitude of this source of $\mathrm{BC}$ to snow is unknown, the PMF analysis suggests this mechanism for getting $\mathrm{BC}$ into snow is not insignificant in some locations. Thus, soil as a source of BC to snow at the USA sites likely explains a substantial portion of the low bias in modeled snow BC for sites in this region with patchy 
snow cover and is also likely the explanation for much of the low bias over the entire data set. We turn next to an assessment of the source attribution of BC in CAM5, including a comparison with the results of a PMF analysis of the North American observations of $\mathrm{BC}$ in snow.

\subsection{Source attribution and emission source efficiency}

\subsubsection{Modeled source-receptor relationships using CAM5}

The direct source tagging method in CAM5 provides a straightforward means of quantifying source-receptor relationships for $\mathrm{BC}$ reaching the receptor regions in North America originating from the various source regions and types. Figure $4 \mathrm{a}$ and $\mathrm{b}$ show relative contributions (as defined in Sect. 2.3, Eq. 3) to the JFM mean BC atmospheric column burden, deposition flux, and near-surface atmospheric concentrations for two receptor regions, the northwestern USA and western Canada (as outlined by white boxes in Fig. 3d). The contributions are shown explicitly for all major source regions and both source types (solid bar for BB and stippled bar for FF). The contributions of BB and FF from minor source regions are lumped together (black bar in Fig. 4a and b). Clearly, FF sources play a primary role in determining atmospheric concentrations and deposition fluxes of BC. Contributions of BB and FF from the North American sources (hereafter, for brevity, we use USA to denote four source regions NWU, NEU, SWU, and SEU; see Fig. 1a for region definitions) increase in importance moving from total column atmospheric burden to deposition fluxes and then to near-surface atmospheric concentrations of BC. North American sources, especially FF sources, are definitely the major sources of BC in the near-surface atmosphere and of BC deposited to the surface - i.e., to snow - as they are within or close to the receptor regions. Long-range transport of BC from distant sources in Asia and Africa (e.g., EAS, SAS, SEA, and AFME) to North America takes place mainly in the middle and upper troposphere (shown in Fig. S8); BC in this part of the atmosphere is less prone to wet removal and thus contributes more to column burden than to near-surface $\mathrm{BC}$ or deposition. The spatial distributions of JFM mean BC column burden and deposition along with BC transport pathways from various distant and domestic source regions and sectors to North America are shown in Figs. S6-S11.

Contributions to $\mathrm{BC}$ atmospheric column burden from all source regions are $38 \% \mathrm{BB}$ and $62 \% \mathrm{FF}$ for the northwestern USA receptor region and $37 \% \mathrm{BB}$ and $63 \% \mathrm{FF}$ for the western Canada receptor region. Contributions to BC column burden from the overseas combination of EAS, SAS, SEA, and AFME to the northwestern USA and western Canada receptor regions are $57 \%(32 \% \mathrm{BB}$ and $25 \% \mathrm{FF})$ and $63 \%$ ( $32 \% \mathrm{BB}$ and $31 \% \mathrm{FF}$ ), respectively, among which $\mathrm{BB}$ from SAS and FF from EAS are the two main overseas sources. Contributions to $\mathrm{BC}$ column burden in the receptor regions
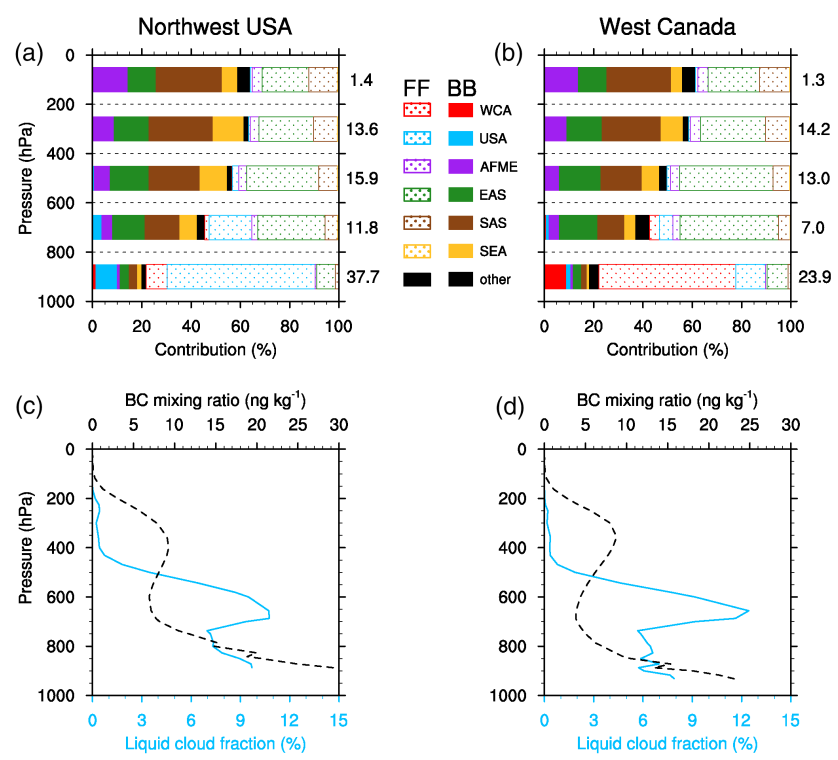

(d) $\quad \mathrm{BC}$ mixing ratio $\left(\mathrm{ng} \mathrm{kg}^{-1}\right)$

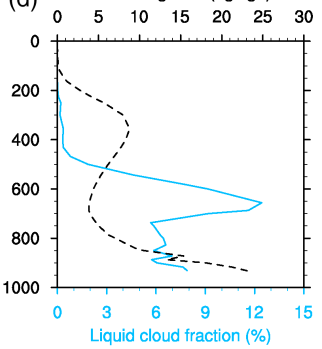

Figure 5. (a) and (b) are similar to Fig. 4a and b, respectively, but for fractional contributions to BC column burden in five separate vertical layers: 0-200, 200-400, 400-600, 600-800 and 800$1000 \mathrm{hPa}$. (c) and (d) show the vertical profiles of area-averaged $\mathrm{BC}$ mixing ratio (in black) and liquid cloud fraction (in blue) over northwestern USA and western Canada, respectively. All fields are from the CAM5 model run.

from the North American source regions (USA and WCA) are $41 \%(5 \% \mathrm{BB}$ and $36 \% \mathrm{FF})$ for the northwestern USA and $34 \%$ (5\% BB and $29 \% \mathrm{FF}$ ) for western Canada.

Relative to that for total column burden, the contribution from FF increases for deposition and is even greater for nearsurface atmospheric BC. Contributions from the combined source regions of USA and WCA to BC deposition over two receptor regions, northwestern USA and western Canada, are $77 \%(10 \% \mathrm{BB}$ and $67 \% \mathrm{FF})$ and $81 \%(11 \% \mathrm{BB}$ and $70 \% \mathrm{FF}$ ), respectively. For near-surface atmospheric BC, the total FF contributions from the USA and WCA (western Canada and Alaska) increase to $82 \%$ (76\% from USA) and $83 \%$ ( $75 \%$ from WCA) over northwestern USA and western Canada, respectively.

Figure $4 c$ and $d$ show emission source efficiency (as defined in Sect. 2.3, Eq. 4) in affecting the three JFM mean $\mathrm{BC}$ properties in both receptor regions. We use this efficiency (assuming a global mean efficiency of 1) as an index to quantify the sensitivity of $\mathrm{BC}$ in a receptor region to a fixed mass perturbation in emissions in different source regions and sectors. It is not surprising that $\mathrm{BC}$ in a given receptor region is most sensitive to local emissions (i.e., NWU for the northwestern USA receptor and WCA for the western Canada receptor). As was the case for source attributions in Fig. 4a and b, the emission source efficiency (Fig. $4 c$ and d) of more local sources is lowest for total atmospheric column burden, then increases for deposition and near-surface atmospheric BC. The distant emission sources have quite low efficiencies, 
with significant non-local contributions only for the total column burden.

Differences in the vertical distribution of contributions to atmospheric BC are shown in more detail in Fig. 5a and b. Modeled vertical profiles of area-averaged $\mathrm{BC}$ mixing ratio and liquid cloud fraction over both receptor regions are also shown, in Fig. 5c and d, to indicate the altitude where wet scavenging of aerosols in clouds is most likely to occur. Clearly, the contribution of local sources significantly decreases above $800 \mathrm{hPa}$, while distant sources become progressively more important at higher altitudes (Fig. 5a and b). $\mathrm{BC}$ from distant sources contribute less to wet scavenging of $\mathrm{BC}$ mass than they do to column burden in the two receptor regions. Liquid clouds are at a maximum in the $600-800 \mathrm{hPa}$ layer. Here, the BC profiles also show a minimum, possibly associated with cloud scavenging of $\mathrm{BC}$ in the model. This layer $(600-800 \mathrm{hPa})$ has an intermediate local source contribution between those in the higher layers and the bottom layer (800-1000 hPa). Above $400 \mathrm{hPa}$, liquid clouds and thus wet removal are minimal. Below $800 \mathrm{hPa}$, below-cloud scavenging by precipitation removes $\mathrm{BC}$ from the air and in this altitude range $\mathrm{BC}$ sources are mostly local. This would increase the local source contribution to the total deposition flux.

\subsubsection{Comparison of source sector attribution between CAM5 and PMF}

Using the procedures described in Sect. 2.4, our PMF source attribution results are compared with the corresponding CAM5 source attributions (Table 1). Comparisons are done for each model grid box where we have a model/observation comparison pair. We reiterate that for both data sets $\mathrm{BB}$ includes emissions from both open biomass burning and biofuel burning.

As discussed in Sect. 2.4, the BB and FF fractions for the PMF analysis are not precisely comparable to those from CAM5 since the PMF analysis has identified an additional BC source, soil, which is not included in the CAM5 simulation. This is reflected in the fact that, while the sum of CAM5 $\mathrm{BB}$ and FF contributions equals 1, the sum of BB and FF contributions from the PMF analysis are commonly less than 1 . Due to the lack of soil source in CAM5 and uncertainties in both measurements and emissions (e.g., spatial distribution of sources and the partitioning between BB and FF sectors), it is not surprising that there are quite large discrepancies between the CAM5 and PMF values for some individual comparison pairs. When compared to the PMF values (which included contributions from FF, BB, and soil), CAM5 underestimates the $\mathrm{BB}$ contribution for $80 \%$ of the comparison pairs (modeled mean and standard deviation of $18 \% \pm 5 \%$ versus PMF values of $28 \% \pm 22 \%$ ) and overestimates the FF contribution for all comparison pairs $(82 \%, \pm 5 \%$ versus $47 \% \pm 21 \%$ ).
Table 1. BB and FF fractional contributions based on the PMF and CAM5 source attribution results for BC in snow for each model/observation comparison pair $(i) . \overline{C_{\mathrm{obs}}^{i}}$ is the mean of the estimated $\mathrm{BC}$ concentrations used in the PMF analysis when more than one sampling sites reside in the same model grid box. $\overline{C_{\text {mod }}^{i}}$ is the JFM mean of CAM5 modeled BC concentrations in snow column. The contributions are calculated as given in Eq. (A1) (observations) and Eq. (A2) (model).

\begin{tabular}{|c|c|c|c|c|c|c|}
\hline $\begin{array}{l}\text { Comparison } \\
\text { pair } i\end{array}$ & $\begin{array}{r}\overline{C_{\mathrm{obs}}^{i}} \\
\left(\mathrm{ng} \mathrm{g}^{-1}\right)\end{array}$ & $\begin{array}{r}\mathrm{BB}_{\mathrm{obs}}^{i} \\
(\%)\end{array}$ & $\begin{array}{r}\mathrm{FF}_{\mathrm{obs}}^{i} \\
(\%)\end{array}$ & $\begin{array}{r}\overline{C_{\text {mod }}^{i}} \\
\left(\mathrm{ng} \mathrm{g}^{-1}\right)\end{array}$ & $\begin{array}{c}\mathrm{BB}_{\bmod }^{i} \\
(\%)\end{array}$ & $\begin{array}{c}\mathrm{FF}_{\bmod }^{i} \\
(\%)\end{array}$ \\
\hline 1 & 15.5 & 62 & 38 & 0.8 & 21 & 79 \\
\hline 2 & 5.8 & 100 & 0 & 9.5 & 28 & 72 \\
\hline 3 & 13.3 & 51 & 49 & 14.7 & 28 & 72 \\
\hline 4 & 14.2 & 70 & 26 & 9.8 & 25 & 75 \\
\hline 5 & 13.7 & 47 & 21 & 15.3 & 26 & 74 \\
\hline 6 & 29.3 & 27 & 47 & 14.3 & 26 & 74 \\
\hline 7 & 24.2 & 27 & 71 & 14.2 & 25 & 75 \\
\hline 8 & 22.0 & 20 & 51 & 12.6 & 23 & 77 \\
\hline 9 & 90.1 & 0 & 0 & 5.4 & 19 & 81 \\
\hline 10 & 28.4 & 16 & 42 & 11.3 & 26 & 74 \\
\hline 11 & 50.6 & 7 & 11 & 10.1 & 16 & 84 \\
\hline 12 & 40.7 & 11 & 26 & 37.1 & 11 & 89 \\
\hline 13 & 17.9 & 34 & 44 & 24.0 & 12 & 88 \\
\hline 14 & 49.5 & 23 & 53 & 52.5 & 13 & 87 \\
\hline 15 & 5.9 & 46 & 52 & 51.8 & 12 & 88 \\
\hline 16 & 25.8 & 16 & 31 & 46.6 & 11 & 89 \\
\hline 17 & 110.6 & 3 & 31 & 30.5 & 14 & 86 \\
\hline 18 & 61.4 & 8 & 61 & 23.3 & 14 & 86 \\
\hline 19 & 24.8 & 13 & 76 & 27.6 & 11 & 89 \\
\hline 20 & 26.9 & 17 & 33 & 39.9 & 12 & 88 \\
\hline 21 & 22.2 & 26 & 56 & 44.5 & 15 & 85 \\
\hline 22 & 17.8 & 31 & 61 & 18.2 & 15 & 85 \\
\hline 23 & 27.5 & 23 & 28 & 12.6 & 15 & 85 \\
\hline 24 & 15.8 & 22 & 63 & 7.2 & 19 & 81 \\
\hline 25 & 14.4 & 32 & 68 & 5.6 & 19 & 81 \\
\hline 26 & 26.0 & 0 & 77 & 12.6 & 15 & 85 \\
\hline 27 & 15.1 & 15 & 48 & 16.0 & 15 & 85 \\
\hline 28 & 18.4 & 16 & 69 & 22.0 & 13 & 87 \\
\hline 29 & 8.4 & 66 & 34 & 29.2 & 15 & 85 \\
\hline 30 & 17.0 & 18 & 75 & 24.8 & 15 & 85 \\
\hline 31 & 8.4 & 45 & 55 & 9.1 & 18 & 82 \\
\hline 32 & 14.7 & 30 & 68 & 20.2 & 15 & 85 \\
\hline 33 & 21.5 & 24 & 61 & 27.3 & 16 & 84 \\
\hline 34 & 17.5 & 18 & 61 & 29.8 & 17 & 83 \\
\hline 35 & 25.0 & 22 & 66 & 38.9 & 16 & 84 \\
\hline
\end{tabular}

For a better quantitative PMF/CAM5 comparison, relative contributions to $\mathrm{BC}$ were also calculated for a PMF analysis allowing for $\mathrm{BC}$ only from direct combustion sources, i.e., the BB and FF sources of BC considered in the CAM5 simulation. Average contributions of $\mathrm{BC}$ from combustion sources only are compared for our two receptor regions in Fig. 6. The two regions differ little in the partitioning of the $\mathrm{BC}$ between $\mathrm{BB}$ and FF sources, but in both regions the PMF indicates a larger role by $\mathrm{BB}$ than the model does. The PMF model attributes $32 \%$ of the $\mathrm{BC}$ to $\mathrm{BB}$ for the northwestern USA region, while for western Canada the fraction is $28 \%$. CAM 5 attributes $16 \%$ of BC in the northwestern USA to $\mathrm{BB}$ and $15 \%$ to $\mathrm{BB}$ in western Canada. Averaging over both regions, the PMF model attributes $30 \%$ of the $\mathrm{BC}$ to 


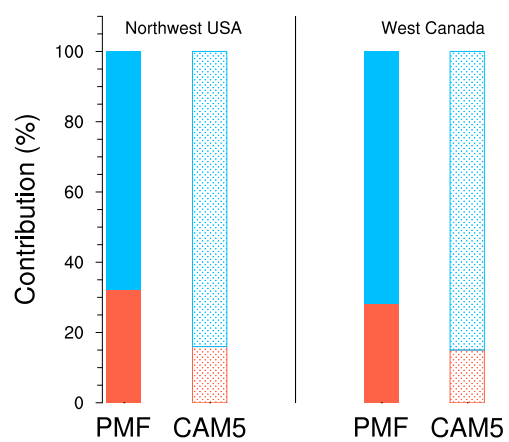

Figure 6. Regional average contributions from BB (red color) and FF (blue color) sector to combustion-sourced BC in snow in northwestern USA and western Canada based on the PMF analysis (solid bar) and CAM5 simulation (stippled bar). The contributions are calculated as in Eq. (A3) (observed values) and Eq. (A4) (modeled values).

BB while CAM5 allocates $16 \%$ to this source. Compared to the PMF results, CAM5 overpredicts the ratio of FF to BB for the North American receptor region.

While certainly significant, the difference in source attribution between CAM5 and the factor analysis is not surprising. The factors that possibly cause the substantial model low bias in BCC could potentially generate biases in the sourcetype attribution. In addition, uncertainties in $\mathrm{BC}$ emission data and model treatment of $\mathrm{BC}$ aging/deposition processes can also be a source of bias in the attribution, including but not limited to (1) the partitioning of BC emissions into fossil fuel and biofuel based on the ratio provided by Dentener et al. (2006); (2) initial injection heights (up to $6 \mathrm{~km}$ ) of biomass burning emissions that directly affect $\mathrm{BC}$ interaction with clouds and its wet deposition in CAM5; (3) treatment of the mixing of hydrophobic BC particles with hygroscopic components (e.g., sulfate and organics) that is important for $\mathrm{BC}$ aging and wet removal but does not differentiate BB or FF origin in the model. These factors, among many others, along with the possible measurement bias for samples with large soil dust concentrations, could explain the difference in source-type attribution between CAM5 and the PMF analysis. The data we have are not sufficient to distinguish between these possible sources of bias.

\subsection{Radiative forcing}

Figure 7 shows the CAM5 modeled JFM mean atmospheric $\mathrm{BC}$ all-sky shortwave direct radiative forcing (DRF) at the surface (dimming effect), at the top of the atmosphere (TOA), and in the atmosphere (heating effect), and it also shows the radiative forcing due to $\mathrm{BC}$ and mineral dust in snow (darkening effect) as a function of latitude (zonally averaged over the longitude band $93.75-123.75^{\circ} \mathrm{W}$ ). The forcing due to $\mathrm{BC}$ is separated out from other aerosol components using the radiation diagnostic calculations recently implemented

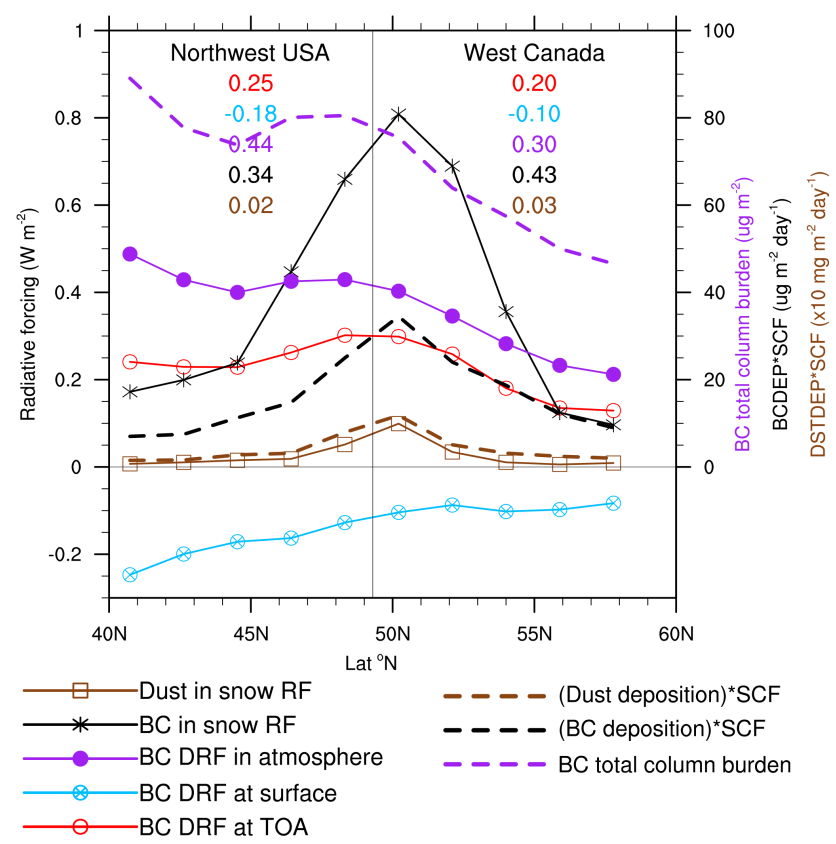

Figure 7. Modeled JFM and zonal mean radiative forcing (RF) values (in $\mathrm{W} \mathrm{m}^{-2}$, using $y$ axis on the left) induced by the various $\mathrm{BC}$ effects and the dust-in-snow effect (indicated by the different colors and symbols in the legend) over the longitude band 93.75$123.75^{\circ} \mathrm{W}$ (white outlines in Fig. 3d). The corresponding areaaverage RF values are shown in colored numbers for northwestern USA and western Canada, respectively. Modeled JFM and zonal mean values of $\mathrm{BC}$ total column burden (in $\mu \mathrm{g} \mathrm{m}^{-2}$ ), BC deposition (in $\mu \mathrm{g} \mathrm{m}^{-2} \mathrm{day}^{-1}$ ) and dust deposition (in $10 \mathrm{mg} \mathrm{m}^{-2} \mathrm{day}^{-1}$ ) multiplied by SCF (snow cover fraction) are shown in colored dashed lines (using $y$ axis on the right).

in CAM5 by Ghan et al. (2012), while the BC- and dustin-snow forcing are calculated in the SNICAR (SNow, ICe, and Aerosol Radiative) model (Flanner et al., 2007), which is coupled to CAM5. The CAM5/SNICAR models do include the light-absorbing effect of mineral dust particles (in addition to BC). Note that the surface radiative forcing due to BC and dust in snow shown here is the total-area mean forcing (i.e., zero values enter the calculation for snow-free grids during the model integration), so this represents the true climate forcing (Flanner et al., 2007).

The DRF by BC in the atmosphere (in-atmosphere heating) decreases with latitude, as does DRF at the surface (cooling). The DRF of $\mathrm{BC}$ at the TOA maximizes around $50^{\circ} \mathrm{N}$, where $\mathrm{BC}$ - and dust-in-snow radiative forcings also reach their maxima. To explain these variations with latitude, we plot the zonal mean of JFM mean BC total column burden in Fig. 7, and we also plot BC and dust deposition scaled by the snow cover fraction (SCF) to weigh the contribution by each grid box to the area mean forcing by $\mathrm{BC}$ and dust in snow. The model estimate of surface SCF was first assessed and found to be in reasonable agreement with the satellite retrievals (shown in Fig. S5). Clearly, the total column burden 
shows the same trend as the DRF in the atmosphere, and the $\mathrm{BC}$ - and dust-in-snow radiative forcing follows the respective latitudinal variations of deposition flux. This suggests that the source attribution for BC DRF in the atmosphere and forcing by $\mathrm{BC}$ in snow could be by approximated using the source-receptor relationships for BC total column burden (Fig. 4) and BC deposition (Table S4), respectively, if one assumes a linear relationship between radiative forcing and $\mathrm{BC}$ concentrations. Note that we did not use such an assumption in the radiative forcing calculation.

The color-coded numbers in Fig. 7 correspond to the various JFM mean radiative forcings averaged over the entire receptor regions, northwestern USA, and western Canada. The BC darkening effect on snow is significant and comparable to its DRF in the atmosphere, especially in western Canada where snow covers almost the entire area (Fig. S5). It is interesting to note that the $\mathrm{BC}$ darkening effect outweighs the $\mathrm{BC}$ dimming effect (i.e., cooling at the surface) and warming effect on the Earth-atmosphere system (i.e., DRF at the TOA) over both of the two regions. The modeled surface radiative forcing due to dust in snow is very small in these regions. However, Doherty et al. (2014) found that local soil dust, which is not considered in the CAM5 simulation, is a significant contributor to light absorption in snow over the U.S. Northern Plains, as well as at some sites in Canada. Intraregionally transported desert dust has also been shown to have a significant impact on snow in the San Juan Mountains of Colorado (e.g., Painter et al., 2010, 2012) and in northwest China (X. Wang et al., 2013; Zhang et al., 2013). This suggests that CAM5 and other climate models that ignore the surface radiative forcing induced by soil and/or desert dust in snow may significantly underestimate the impact of lightabsorbing impurities on snowmelt and climate.

\section{Summary and conclusions}

In this study, the CAM5 global model, implemented with an explicit $\mathrm{BC}$ source tagging technique, has been employed to establish source-receptor relationships for atmospheric BC and its deposition to snow over a large receptor area encompassing a substantial portion of the Great Plains of North America. The model meteorological fields are constrained to agree with the MERRA reanalysis data sets for the year 2013. Model-predicted near-surface atmospheric BC concentrations and BC-in-snow concentrations in January, February, and March (JFM) were evaluated against atmospheric observations from the IMPROVE network and field measurements from a recent large-area survey of BC (and other lightabsorbing particles) in snow over land (Doherty et al., 2014), respectively. We found that CAM5 had a small low bias (11\%) but a substantial random error (about a factor of 2) in the estimates of monthly-mean near-surface atmospheric BC concentrations. However, the model had a substantial error (a factor of 2) and a larger negative bias (37\%) in the pre- diction of BC-in-snow concentrations at all the snow sampling sites. A common explanation for a low bias in model predictions of atmospheric $\mathrm{BC}$ has been an underestimate of $\mathrm{BC}$ emissions and/or an overestimate of removal during the transport. However, systematic biases in emissions and/or model processes should show up consistently in both atmospheric BC and BC in snow and/or in adjacent geographic regions of sampling sites. Analysis of the geographic variation in the bias and error in modeled $\mathrm{BC}$ in snow versus that observed, along with the model-observational comparison of the atmospheric near-surface $\mathrm{BC}$ at the US sites, suggests that the negative model bias is more likely due to the lack of a soil source for BC in patchy snow rather than an underestimation of direct combustion emissions in the model simulation. Patchy snow at the US sites is prone to contamination of soil dust originating from the exposed soil areas. The soil dust may contain $\mathrm{BC}$ deposited from the atmosphere, which was not included in the emission inventory for the CAM5 simulation. Although our analysis supports this plausible explanation for the larger BC-in-snow model bias at the US sites, an underestimation of regional $\mathrm{BC}$ emissions still cannot be excluded as a cause of the model-observational difference. It is also possible that some of the difference between model and observation is due to a high bias in the measurements when $\mathrm{BC}$ is mixed with significant amounts of lightabsorbing soil dust. However, the relatively good modelobservational agreement for the Canadian sites makes it unlikely that $\mathrm{BC}$-in-snow measurement bias is the sole source of the discrepancy between the CAM5 predications and the field observations.

The explicit direct source tagging technique in CAM5 permits a quantitative attribution of $\mathrm{BC}$ in receptor regions (northwestern USA and western Canada) to source regions (North American or more distant emissions) and source types (fossil fuel, FF, versus biomass/biofuel, BB). In the model, local sources generally contribute more to near-surface BC and deposition than distant sources. However, distant sources contribute significantly to the column BC burden, especially to $\mathrm{BC}$ in the middle and upper troposphere. At these altitudes wet removal is relatively weak, so little of this BC likely reaches the surface snowpack. In the model, FF is the dominant source type for total column $\mathrm{BC}$ over the two receptor regions. FF is also the dominant local source type for $\mathrm{BC}$ column burden, deposition, and near-surface BC. However, for all distant source regions combined the contribution of $\mathrm{BB}$ is larger than FF.

An observationally based PMF analysis of the sources of BC to snow, based on snow chemistry, is compared to the CAM5 source attribution based on source tagging. While the CAM5 source attribution was biased high for the FF sector and low for the BB sector compared to PMF, they both show that the contribution of the FF sector is much larger than that of the BB sector. For the two receptor regions examined in this study (northwestern USA and northwestern Canada), the relative contribution of the $\mathrm{BB}$ sector was underestimated by 
about a factor of 2 in CAM5 relative to that given by the PMF analysis. The quantitative difference in the source-type attribution between CAM5 and PMF analysis could be due to an underestimation of North American BB emissions, the lack of a soil source of $\mathrm{BC}$ with a high $\mathrm{BB} / \mathrm{FF}$ ratio in the model, model treatment of aerosol aging/deposition processes such that the wet removal rate of $\mathrm{BC}$ from the $\mathrm{BB}$ sector is overestimated, and/or biases in the measurements.

Based on the CAM5 predictions of BC concentrations in both the air and snow, and of dust in snow, radiative forcing calculations were carried out for our two North American receptor regions (Fig. 3d). The darkening effect of $\mathrm{BC}$ in surface snow (i.e., snow albedo reduction due to the presence of BC) is substantially larger than the BC dimming effect (i.e., reduction in surface radiative flux due to $\mathrm{BC}$ in the atmosphere) but is comparable to $\mathrm{BC}$ heating in the atmosphere. The modeled surface radiative forcing due to dust in snow is small in the two regions. However, Doherty et al. (2014) found that local soil, which is not considered in the CAM5 simulation, is a significant contributor to light absorption in snow, suggesting that CAM5 and other climate models that ignore the local soil contributions to snow may significantly underestimate the impact of light-absorbing impurities on snowmelt and climate. 


\section{Appendix A}

The average fractional contributions by the $\mathrm{BB}$ and FF sources from the PMF analysis for each of the snow samples sites $(k)$ falling within a given model grid box are calculated using Eq. (A1).

$$
\begin{aligned}
& \mathrm{BB}_{\mathrm{obs}}^{i}= \frac{\sum_{k=1}^{\mathrm{S}} C_{\mathrm{obs}}^{k} \times f_{\mathrm{BB}}^{k}}{\sum_{k=1}^{\mathrm{S}} C_{\mathrm{obs}}^{k} \times\left(f_{\mathrm{BB}}^{k}+f_{\mathrm{FF}}^{k}+f_{\mathrm{soil}}^{k}\right)}, \\
& \mathrm{FF}_{\mathrm{obs}}^{i}=\frac{\sum_{k=1}^{\mathrm{S}} C_{\mathrm{obs}}^{k} \times f_{\mathrm{FF}}^{k}}{\sum_{k=1}^{\mathrm{S}} C_{\mathrm{obs}}^{k} \times\left(f_{\mathrm{BB}}^{k}+f_{\mathrm{FF}}^{k}+f_{\mathrm{soil}}^{k}\right)},
\end{aligned}
$$

where $f_{\mathrm{BB}}^{k}+f_{\mathrm{FF}}^{k}+f_{\mathrm{soil}}^{k}=1$. $C_{\mathrm{obs}}^{k}$ is the estimated snow $\mathrm{BC}$ concentrations used in the PMF analysis for the snow sampling site $k$ (Table S2). "S" is the total number of sampling sites within the same model grid box.

The CAM5 JFM mean fractional contributions for the $\mathrm{BB}$ and FF sectors in each model grid box, where observational/PMF data are available, are calculated using Eq. (A2).

$$
\begin{aligned}
\mathrm{BB}_{\mathrm{mod}}^{i} & =\frac{\sum_{j=1}^{\mathrm{M}} C_{\mathrm{mod}}^{j} \times D_{\mathrm{BB}}^{j}}{\sum_{j=1}^{\mathrm{M}} C_{\mathrm{mod}}^{j} \times\left(D_{\mathrm{BB}}^{j}+D_{\mathrm{FF}}^{j}\right)}, \\
\mathrm{FF}_{\mathrm{mod}}^{i}= & \frac{\sum_{j=1}^{\mathrm{M}} C_{\mathrm{mod}}^{j} \times D_{\mathrm{FF}}^{j}}{\sum_{j=1}^{\mathrm{M}} C_{\mathrm{mod}}^{j} \times\left(D_{\mathrm{BB}}^{j}+D_{\mathrm{FF}}^{j}\right)},
\end{aligned}
$$

where $C_{\text {mod }}^{j}$ is the modeled snow BC concentration in month $j$ for the model grid box $i . D_{\mathrm{BB}}^{j}$ and $D_{\mathrm{FF}}^{j}$ are fractional contributions of $\mathrm{BB}$ and $\mathrm{FF}$ deposition, respectively, to total BC deposition in month $j$, and $D_{\mathrm{BB}}^{j}+D_{\mathrm{FF}}^{j}=1$. "M" is 3 (total number of months).

The regional average of fractional contributions from the $\mathrm{BB}$ and FF sectors from the PMF analysis and from the CAM5 simulation is calculated using Eqs. (A3) and (A4), respectively.

$$
\begin{aligned}
& \overline{\mathrm{BB}_{\mathrm{obs}}}=\frac{\sum_{n=1}^{N} \overline{C_{\mathrm{obs}}^{n}} \times \mathrm{BB}_{\mathrm{obs}}^{n}}{\sum_{n=1}^{N} \overline{C_{\mathrm{obs}}^{n}} \times\left(\mathrm{BB}_{\mathrm{obs}}^{n}+\mathrm{FF}_{\mathrm{obs}}^{n}\right)}, \\
& \overline{\mathrm{FF}_{\mathrm{obs}}}=\frac{\sum_{n=1}^{N} \overline{C_{\mathrm{obs}}^{n}} \times \mathrm{FF}_{\mathrm{obs}}^{n}}{\sum_{n=1}^{N} \overline{C_{\mathrm{obs}}^{n}} \times\left(\mathrm{BB}_{\mathrm{obs}}^{n}+\mathrm{FF}_{\mathrm{obs}}^{n}\right)}, \\
& \overline{\mathrm{BB}_{\mathrm{mod}}}=\frac{\sum_{n=1}^{N} \overline{C_{\mathrm{mod}}^{n}} \times \mathrm{BB}_{\mathrm{mod}}^{n}}{\sum_{n=1}^{N} \overline{C_{\mathrm{mod}}^{n}} \times\left(\mathrm{BB}_{\mathrm{mod}}^{n}+\mathrm{FF}_{\mathrm{mod}}^{n}\right)}, \\
& \overline{\mathrm{FF}_{\mathrm{mod}}}=\frac{\sum_{n=1}^{N} \overline{C_{\bmod }^{n}} \times \mathrm{FF}_{\mathrm{mod}}^{n}}{\sum_{n=1}^{N} \overline{C_{\mathrm{mod}}^{n}} \times\left(\mathrm{BB}_{\mathrm{mod}}^{n}+\mathrm{FF}_{\mathrm{mod}}^{n}\right)},
\end{aligned}
$$

where $N$ is the total number of observation/model comparison pairs $(n)$ in a given region. 


\section{The Supplement related to this article is available online at doi:10.5194/acp-15-12805-2015-supplement.}

Acknowledgements. This research is based on work supported by the US Department of Energy (DOE), Office of Science, Biological and Environmental Research as part of the Earth System Modeling Program. The Pacific Northwest National Laboratory (PNNL) is operated for DOE by Battelle Memorial Institute under contract DE-AC05-76RLO1830. The CESM project is supported by the National Science Foundation and the DOE Office of Science. D. A. Hegg, S. J. Doherty, C. Dang, and Q. Fu acknowledge support from the EPA STAR grant RD-82503801. R. Zhang acknowledges support from the China Scholarship Fund. We gratefully thank Stephen G. Warren for helpful advice and discussion on using the snow impurity data. ECLIPSE emission data sets are available from http://www.geiacenter.org/access. Funding for the development of the ECLIPSE emission data set was provided by the European Union Seventh Framework Program (FP7/2007-2013) under grant agreement no. 282688 - ECLIPSE. The IMPROVE network data were made available at http://vista.cira.colostate.edu/improve/. Computational resources were provided by the National Energy Research Scientific Computing Center (NERSC), a national scientific user facility located at Lawrence Berkeley National Laboratory in Berkeley, California. NERSC is the flagship scientific computing facility for the Office of Science in DOE. A portion of the research was performed using DOE EMSL Molecular Sciences Computing resources located at PNNL.

Edited by: D. Spracklen

\section{References}

Amann, M., Bertok, I., Borken-Kleefeld, J., Cofala, J., Heyes, C., Höglund-Isaksson, L., Klimont, Z., Nguyen, B., Posch, M., Rafaj, P., Sandler, R., Schöpp, W., Wagner, F., and Winiwarter, W.: Cost-effective control of air quality and greenhouse gases in Europe: Modeling and policy applications, Environ. Model. Softw., 26, 1489-1501, 2011.

Bond, T. C., Doherty, S. J., Fahey, D. W., Forster, P. M., Berntsen, T., DeAngelo, B. J., Flanner, M. G., Ghan, S., Kärcher, B., Koch, D., Kinne, S., Kondo, Y., Quinn, P. K., Sarofim, M. C., Schultz, M. G., Schulz, M., Venkataraman, C., Zhang, H., Zhang, S., Bellouin, N., Guttikunda, S. K., Hopke, P. K., Jacobson, M. Z., Kaiser, J. W., Klimont, Z., Lohmann, U., Schwarz, J. P., Shindell, D., Storelvmo, T., Warren, S. G., and Zender, C. S.: Bounding the role of black carbon in the climate system: A scientific assessment, J. Geophys. Res.-Atmos., 118, 5380-5552, doi:10.1002/jgrd.50171, 2013.

Chin, M., Diehl, T., Ginoux, P., and Malm, W.: Intercontinental transport of pollution and dust aerosols: implications for regional air quality, Atmos. Chem. Phys., 7, 5501-5517, doi:10.5194/acp7-5501-2007, 2007.

Chow, J. C., Watson, J. G., Pritchett, L. C., Pierson, W. R., Frazier, C. A., and Purcell, R. G.: The DRI Thermal/Optical Reflectance carbon analysis system: Description, evaluation and applications in US air quality studies, Atmos. Environ. A, 27, 1185-1201, 1993.
Chow, J. C., Watson, J. G., Chen, L.-W. A., Chang, M. C. O., Robinson, N. F., Trimble, D., and Kohl, S. D.: The IMPROVE_A temperature protocol for thermal/optical carbon analysis: Maintaining consistency with a long-term database, J. Air Waste Manage. Assoc., 57, 1014-1023, 2007.

Clarke, A. D. and Kapustin, V.: Hemispheric aerosol vertical profiles: Anthropogenic impacts on optical depth and cloud nuclei, Science, 329, 1488-1492, 2010.

Clarke, A. D. and Noone, K. J.: Soot in Arctic snow: a cause for perturbations of radiative transfer, Atmos. Environ., 19, 20452053, 1985.

Dang, C. and Hegg, D. A.: Quantifying light absorption by organic carbon in Western North American snow by serial chemical extractions, J. Geophys. Res.-Atmos., 119, 10247-10261, doi:10.1002/2014JD022156, 2014.

Dentener, F., Kinne, S., Bond, T., Boucher, O., Cofala, J., Generoso, S., Ginoux, P., Gong, S., Hoelzemann, J. J., Ito, A., Marelli, L., Penner, J. E., Putaud, J.-P., Textor, C., Schulz, M., van der Werf, G. R., and Wilson, J.: Emissions of primary aerosol and precursor gases in the years 2000 and 1750 prescribed data-sets for AeroCom, Atmos. Chem. Phys., 6, 4321-4344, doi:10.5194/acp-64321-2006, 2006.

Doherty, S. J., Warren, S. G., Grenfell, T. C., Clarke, A. D., and Brandt, R. E.: Light-absorbing impurities in Arctic snow, Atmos. Chem. Phys., 10, 11647-11680, doi:10.5194/acp-1011647-2010, 2010.

Doherty, S. J., Grenfell, T. C., Forsström, S., Hegg, D. L., Brandt, R. E., and Warren, S. G.: Observed vertical redistribution of black carbon and other insoluble light-absorbing particles in melting snow, J. Geophys. Res.-Atmos., 118, 5553-5569, doi:10.1002/jgrd.50235, 2013.

Doherty, S. J., Dang, C., Hegg, D. A., Zhang, R., and Warren, S. G.: Black carbon and other light-absorbing particles in snow of central North America, J. Geophys. Res.-Atmos., 119, 12807 12831, doi:10.1002/2014JD022350, 2014.

Eguchi, K., Uno, I., Yumimoto, K., Takemura, T., Shimizu, A., Sugimoto, N., and Liu, Z.: Trans-pacific dust transport: integrated analysis of NASA/CALIPSO and a global aerosol transport model, Atmos. Chem. Phys., 9, 3137-3145, doi:10.5194/acp-93137-2009, 2009.

Fagerli, H., Legrand, M., Preunkert, S., Vestreng, V., Simpson, D., and Cerqueira, M.: Modeling historical long-term trends of sulfate, ammonium, and elemental carbon over Europe: A comparison with ice core records in the Alps, J. Geophys. Res.-Atmos., 112, D23s13, doi:10.1029/2006jd008044, 2007.

Fischer, E. V., Jaffe, D. A., Marley, N. A., Gaffney, J. S., and Marchany-Rivera, A.: Optical properties of aged Asian aerosols observed over the US Pacific Northwest, J. Geophys. Res., 115, D20209, doi:10.1029/2010JD013943, 2010.

Flanner, M. G., Zender, C. S., Randerson, J. T., and Rasch, P. J.: Present day climate forcing and response from black carbon in snow, J. Geophys. Res., 112, D11202, doi:10.1029/2006JD008003, 2007.

Flanner, M. G., Zender, C. S., Hess, P. G., Mahowald, N. M., Painter, T. H., Ramanathan, V., and Rasch, P. J.: Springtime warming and reduced snow cover from carbonaceous particles, Atmos. Chem. Phys., 9, 2481-2497, doi:10.5194/acp-9-24812009, 2009. 
Ghan, S. J., Liu, X., Easter, R. C., Zaveri, R., Rasch, P. J., Yoon, J.H., and Eaton, B.: Toward a minimal representation of aerosols in climate models: Comparative decomposition of aerosol direct, semi-direct and indirect radiative forcing, J. Climate, 25, 64616476, doi:10.1175/JCLI-D-11-00650.1, 2012.

Graf, H.-F., Shirsat, S. V., Oppenheimer, C., Jarvis, M. J., Podzun, R., and Jacob, D.: Continental scale Antarctic deposition of sulphur and black carbon from anthropogenic and volcanic sources, Atmos. Chem. Phys., 10, 2457-2465, doi:10.5194/acp-10-24572010, 2010.

Grenfell, T. C., Doherty, S. J., Clarke, A. D., and Warren, S. G.: Light absorption from particulate impurities in snow and ice determined by spectrophotometric analysis of filters, Appl. Optics, 50, 2037-2048, 2011.

Hadley, O. L., Ramanathan, V., Carmichael, G. R., Tang, Y., Corrigan, C. E., Roberts, G. C., and Mauger, G. S.: Trans-Pacific transport of black carbon and fine aerosols $(D<2.5 \mu \mathrm{m})$ into North America, J. Geophys. Res., 112, D05309, doi:10.1029/2006JD007632, 2007.

Hansen, J. and Nazarenko, L.: Soot climate forcing via snow and ice albedos, P. Natl. Acad. Sci. USA, 101, 423-428, doi:10.1073/pnas.2237157100, 2004.

Heald, C. L., Jacob, D. J., Park, R. J., Alexander, B., Fairlie, T. D., Yantosca, R. M., and Chu, D. A.: Transpacific transport of Asian anthropogenic aerosols and its impact on surface air quality in the United States, J. Geophys. Res.-Atmos., 111, D14310, doi:10.1029/2005JD006847, 2006.

Hegarty, J., Zabowski, D., and Bakker, J. D.: Use of soil properties to determine the historical extent of two western Washington prairies, Northwest Sci., 85, 120-129, 2011.

Hegg, D. A., Warren, S. G., Grenfell, T. C., Doherty, S. J., Larson, T. V., and Clarke, A. D.: Source Attribution of Black Carbon in Arctic Snow, Environ. Sci. Technol., 43, 4016-4021, doi:10.1021/es803623f, 2009.

Hegg, D. A., Warren, S. G., Grenfell, T. C., Doherty, S. J., and Clarke, A. D.: Sources of light-absorbing aerosol in arctic snow and their seasonal variation, Atmos. Chem. Phys., 10, 1092310938, doi:10.5194/acp-10-10923-2010, 2010.

Hirdman, D., Burkhart, J. F., Sodemann, H., Eckhardt, S., Jefferson, A., Quinn, P. K., Sharma, S., Ström, J., and Stohl, A.: Long term trends of black carbon and sulphate aerosol in the Arctic: changes in atmospheric transport and source region emissions, Atmos. Chem. Phys., 10, 9351-9368, doi:10.5194/acp-10-93512010, 2010a.

Hirdman, D., Sodemann, H., Eckhardt, S., Burkhart, J. F., Jefferson, A., Mefford, T., Quinn, P. K., Sharma, S., Ström, J., and Stohl, A.: Source identification of short-lived air pollutants in the Arctic using statistical analysis of measurement data and particle dispersion model output, Atmos. Chem. Phys., 10, 669-693, doi:10.5194/acp-10-669-2010, 2010b.

Huang, J., Fu, Q., Zhang, W., Wang, X., Zhang, R., Ye, H., and Warren, S. G.: Dust and black carbon in seasonal snow across Northern China, B. Am. Meteorol. Soc., 92, 175-181, doi:10.1175/2010BAMS3064.1, 2011.

Huang, L., Gong, S. L., Jia, C. Q., and Lavoue, D.: Relative contributions of anthropogenic emissions to black carbon aerosol in the Arctic, J. Geophys. Res.-Atmos., 115, D19208, doi:10.1029/2009jd013592, 2010.
IPCC: Summary for Policymakers, in: Climate Change 2013: The Physical Science Basis, Contribution of Working Group I to the Fifth Assessment Report of the Intergovernmental Panel on Climate Change, edited by: Stocker, T. F., Qin, D., Plattner, G.-K., Tignor, M., Allen, S. K., Boschung, J., Nauels, A., Xia, Y., Bex, V., and Midgley, P.M., Cambridge University Press, Cambridge, UK and New York, NY, USA, 2013.

Jacobson, M. Z.: Climate response of fossil fuel and biofuel soot, accounting for soot's feedback to snow and sea ice albedo and emissivity, J. Geophys. Res., 109, D21201, doi:10.1029/2004JD004945, 2004.

Jacobson, M. Z.: Short-term effects of controlling fossil-fuel soot, biofuel soot and gases, and methane on climate, Arctic ice, and air pollution health, J. Geophys. Res.-Atmos., 115, D14209, doi:10.1029/2009jd013795, 2010.

Jaffe, D., Anderson, T., Covert, D., Kotchenruther, R., Trost, B., Danielson, J., Simpson, W., Berntsen, T., Karlsdottir, S., Blake, D., Harris, J., Carmichael, G., and Uno, I.: Transport of Asian air pollution to North America, Geophys. Res. Lett., 26, 711-714, 1999.

Jiao, C., Flanner, M. G., Balkanski, Y., Bauer, S. E., Bellouin, N., Berntsen, T. K., Bian, H., Carslaw, K. S., Chin, M., De Luca, N., Diehl, T., Ghan, S. J., Iversen, T., Kirkevåg, A., Koch, D., Liu, X., Mann, G. W., Penner, J. E., Pitari, G., Schulz, M., Seland, Ø., Skeie, R. B., Steenrod, S. D., Stier, P., Takemura, T., Tsigaridis, K., van Noije, T., Yun, Y., and Zhang, K.: An AeroCom assessment of black carbon in Arctic snow and sea ice, Atmos. Chem. Phys., 14, 2399-2417, doi:10.5194/acp-14-2399-2014, 2014.

Koch, D., Schulz, M., Kinne, S., McNaughton, C., Spackman, J. R., Balkanski, Y., Bauer, S., Berntsen, T., Bond, T. C., Boucher, O., Chin, M., Clarke, A., De Luca, N., Dentener, F., Diehl, T., Dubovik, O., Easter, R., Fahey, D. W., Feichter, J., Fillmore, D., Freitag, S., Ghan, S., Ginoux, P., Gong, S., Horowitz, L., Iversen, T., Kirkevåg, A., Klimont, Z., Kondo, Y., Krol, M., Liu, X., Miller, R., Montanaro, V., Moteki, N., Myhre, G., Penner, J. E., Perlwitz, J., Pitari, G., Reddy, S., Sahu, L., Sakamoto, H., Schuster, G., Schwarz, J. P., Seland, Ø., Stier, P., Takegawa, N., Takemura, T., Textor, C., van Aardenne, J. A., and Zhao, Y.: Evaluation of black carbon estimations in global aerosol models, Atmos. Chem. Phys., 9, 9001-9026, doi:10.5194/acp-9-9001-2009, 2009.

Kopacz, M., Mauzerall, D. L., Wang, J., Leibensperger, E. M., Henze, D. K., and Singh, K.: Origin and radiative forcing of black carbon transported to the Himalayas and Tibetan Plateau, Atmos. Chem. Phys., 11, 2837-2852, doi:10.5194/acp-11-28372011, 2011.

Lamarque, J.-F., Bond, T. C., Eyring, V., Granier, C., Heil, A., Klimont, Z., Lee, D., Liousse, C., Mieville, A., Owen, B., Schultz, M. G., Shindell, D., Smith, S. J., Stehfest, E., Van Aardenne, J., Cooper, O. R., Kainuma, M., Mahowald, N., McConnell, J. R., Naik, V., Riahi, K., and van Vuuren, D. P.: Historical (1850-2000) gridded anthropogenic and biomass burning emissions of reactive gases and aerosols: methodology and application, Atmos. Chem. Phys., 10, 7017-7039, doi:10.5194/acp10-7017-2010, 2010.

Law, K. S. and Stohl, A.: Arctic air pollution: Origins and impacts, Science, 315, 1537-1540, 2007.

Lee, Y. H., Lamarque, J.-F., Flanner, M. G., Jiao, C., Shindell, D. T., Berntsen, T., Bisiaux, M. M., Cao, J., Collins, W. J., Cur- 
ran, M., Edwards, R., Faluvegi, G., Ghan, S., Horowitz, L. W., McConnell, J. R., Ming, J., Myhre, G., Nagashima, T., Naik, V., Rumbold, S. T., Skeie, R. B., Sudo, K., Takemura, T., Thevenon, F., Xu, B., and Yoon, J.-H.: Evaluation of preindustrial to presentday black carbon and its albedo forcing from Atmospheric Chemistry and Climate Model Intercomparison Project (ACCMIP), Atmos. Chem. Phys., 13, 2607-2634, doi:10.5194/acp13-2607-2013, 2013.

Levis, S., Bonan, G. B., and Lawrence, P. J.: Present-day springtime high-latitude surface albedo as a predictor of simulated climate sensitivity, Geophys. Res. Lett., 34, L17703, doi:10.1029/2007GL030775, 2007.

Lu, Z., Streets, D. G., Zhang, Q., and Wang, S.: A novel backtrajectory analysis of the origin of black carbon transported to the Himalayas and Tibetan Plateau during 1996-2010, Geophys. Res. Lett., 39, L01809, doi:10.1029/2011GL049903, 2012.

Lubin, D. and Vogelmann, A. M.: A climatologically significant aerosol longwave indirect effect in the Arctic, Nature, 439, 453456, doi:10.1038/nature04449, 2006.

Ma, P.-L., Rasch, P. J., Wang, H., Zhang, K., Easter, R. C., Tilmes, S., Fast, J. D., Liu, X., Yoon, J.-H., and Lamarque, J.-F.: The role of circulation features on black carbon transport into the Arctic in the Community Atmosphere Model Version 5 (CAM5), J. Geophys. Res.-Atmos., 118, 4657-4669, 2013.

Malm, W. C., Sisler, J. F., Huffman, D., Eldred, R. A., and Cahill, T. A.: Spatial and seasonal trends in particle concentration and optical extinction in the United States, J. Geophys. Res., 99, 13471370, 1994.

Mao, Y. H., Li, Q. B., Zhang, L., Chen, Y., Randerson, J. T., Chen, D., and Liou, K. N.: Biomass burning contribution to black carbon in the Western United States Mountain Ranges, Atmos. Chem. Phys., 11, 11253-11266, doi:10.5194/acp-1111253-2011, 2011.

Ming, J., Cachier, H., Xiao, C., Qin, D., Kang, S., Hou, S., and $\mathrm{Xu}, \mathrm{J}$.: Black carbon record based on a shallow Himalayan ice core and its climatic implications, Atmos. Chem. Phys., 8, 1343 1352, doi:10.5194/acp-8-1343-2008, 2008.

Painter, T. H., Deems, J. S., Belnap, J., Hamlet, A. F., Landry, C. C., and Udall, B.: Response of Colorado River runoff to dust radiative forcing in snow, P. Natl. Acad. Sci., 107, 17125-17130, doi:10.1073/pnas.0913139107, 2010.

Painter, T. H., Skiles, S. M., Deems, J. S., Bryant, A. C., and Landry, C. C.: Dust radiative forcing in snow of the Upper Colorado River Basin: 1. A 6 year record of energy balance, radiation, and dust concentrations, Water Resour. Res., 48, W07521, doi:10.1029/2012WR011985, 2012.

Park, R. J., Jacob, D. J., Palmer, P. I., Clarke, A. D., Weber, R. J., Zondlo, M. A., Eisele, F. L., Bandy, A. R., Thornton, D. C., Sachse, G. W., and Bond, T. C.: Export efficiency of black carbon aerosol in continental outflow: Global implications, J. Geophys. Res.-Atmos., 110, D11205, doi:10.1029/2004JD005432, 2005.

Qian, Y., Flanner, M. G., Leung, L. R., and Wang, W.: Sensitivity studies on the impacts of Tibetan Plateau snowpack pollution on the Asian hydrological cycle and monsoon climate, Atmos. Chem. Phys., 11, 1929-1948, doi:10.5194/acp-11-19292011, 2011.

Qian, Y., Wang, H., Zhang, R., Flanner, M. G., and Rasch, P. J.: A sensitivity study on modeling black carbon in snow and its radiative forcing over the Arctic and Northern China, Environ. Res. Lett., 9, 064001, doi:10.1088/1748-9326/9/6/064001, 2014 Qian, Y., Yasunari, T. J., Doherty, S. J., Flanner, M. G., Lau, W. K., Ming, J., Wang, H., Wang, M., Warren, S. G., and Zhang, R.: Light-absorbing particles in snow and ice: Measurement and modeling of climatic and hydrological impact, Adv. Atmos. Sci., 32, 64-91, 2015.

Rienecker, M. M., Suarez, M. J., Gelaro, R., Todling, R., Bacmeister, J., Liu, E., Bosilovich, M. G., Schubert, S. D., Takacs, L., Kim, G.-K., Bloom, S., Chen, J., Collins, D., Conaty, A., da Silva, A., Gu, W., Joiner, J., Koster, R. D., Lucchesi, R., and Molod, A.: MERRA - NASA's Modern-Era Retrospective Analysis for Research and Applications, J. Climate, 24, 3624-3648, 2011.

Sand, M., Berntsen, T. K., Seland, Ø., and Kristjansson, J. E.: Arctic surface temperature change to emissions of black carbon within Arctic or midlatitudes, J. Geophys. Res., 118, 7788-7798, doi:10.1002/jgrd.50613, 2013.

Schmidt, M. W. I. and Noack, A. G.: Black carbon in soils and sediments: Analysis, distribution, implications, and current challenges, Global Biogeochem. Cy., 14, 777-793, 2000.

Schwarz, J. P., Doherty, S. J., Li, F., Ruggiero, S. T., Tanner, C. E., Perring, A. E., Gao, R. S., and Fahey, D. W.: Assessing Single Particle Soot Photometer and Integrating Sphere/Integrating Sandwich Spectrophotometer measurement techniques for quantifying black carbon concentration in snow, Atmos. Meas. Tech., 5, 2581-2592, doi:10.5194/amt-5-2581-2012, 2012.

Sharma, S., Andrews, E., Barrie, L. A., Ogren, J. A., and Lavoue, D.: Variations and sources of the equivalent black carbon in the high Arctic revealed by long-term observations at Alert and Barrow: 1989-2003, J. Geophys. Res., 111, D14208, doi:10.1029/2005JD006581, 2006.

Sharma, S., Ishizawa, M., Chan, D., Lavoué, D., Andrews, E., Eleftheriadis, K., and Maksyutov, S.: 16-year simulation of Arctic black carbon: Transport, source contribution, and sensitivity analysis on deposition, J. Geophys. Res.-Atmos., 118, 943-964, doi:10.1029/2012JD017774, 2013.

Shindell, D. T. and Faluvegi, G.: Climate response to regional radiative forcing during the twentieth century, Nat. Geosci., 2, 294 300, 2009.

Shindell, D. T., Chin, M., Dentener, F., Doherty, R. M., Faluvegi, G., Fiore, A. M., Hess, P., Koch, D. M., MacKenzie, I. A., Sanderson, M. G., Schultz, M. G., Schulz, M., Stevenson, D. S., Teich, H., Textor, C., Wild, O., Bergmann, D. J., Bey, I., Bian, H., Cuvelier, C., Duncan, B. N., Folberth, G., Horowitz, L. W., Jonson, J., Kaminski, J. W., Marmer, E., Park, R., Pringle, K. J., Schroeder, S., Szopa, S., Takemura, T., Zeng, G., Keating, T. J., and Zuber, A.: A multi-model assessment of pollution transport to the Arctic, Atmos. Chem. Phys., 8, 5353-5372, doi:10.5194/acp-85353-2008, 2008.

Skeie, R. B., Berntsen, T., Myhre, G., Pedersen, C. A., Ström, J., Gerland, S., and Ogren, J. A.: Black carbon in the atmosphere and snow, from pre-industrial times until present, Atmos. Chem. Phys., 11, 6809-6836, doi:10.5194/acp-11-6809-2011, 2011.

Stohl, A.: Characteristics of atmospheric transport into the Arctic troposphere, J. Geophys. Res.-Atmos., 111, D11306, doi:10.1029/2005jd006888, 2006.

Stohl, A., Klimont, Z., Eckhardt, S., Kupiainen, K., Shevchenko, V. P., Kopeikin, V. M., and Novigatsky, A. N.: Black carbon in 
the Arctic: the underestimated role of gas flaring and residential combustion emissions, Atmos. Chem. Phys., 13, 8833-8855, doi:10.5194/acp-13-8833-2013, 2013.

Stohl, A., Aamaas, B., Amann, M., Baker, L. H., Bellouin, N., Berntsen, T. K., Boucher, O., Cherian, R., Collins, W., Daskalakis, N., Dusinska, M., Eckhardt, S., Fuglestvedt, J. S., Harju, M., Heyes, C., Hodnebrog, Ø., Hao, J., Im, U., Kanakidou, M., Klimont, Z., Kupiainen, K., Law, K. S., Lund, M. T., Maas, R., MacIntosh, C. R., Myhre, G., Myriokefalitakis, S., Olivié, D., Quaas, J., Quennehen, B., Raut, J.-C., Rumbold, S. T., Samset, B. H., Schulz, M., Seland, Ø., Shine, K. P., Skeie, R. B., Wang, S., Yttri, K. E., and Zhu, T.: Evaluating the climate and air quality impacts of short-lived pollutants, Atmos. Chem. Phys., 15, 10529-10566, doi:10.5194/acp-15-10529-2015, 2015.

VanCuren, R. A.: Asian aerosols in North America: Extracting the chemical composition and mass concentration of the Asian continental aerosol plume from long-term aerosol records in the western United States, J. Geophys. Res., 108, 4623, doi:10.1029/2003JD003459, 2003.

van der Werf, G. R., Randerson, J. T., Giglio, L., Collatz, G. J., Mu, M., Kasibhatla, P. S., Morton, D. C., DeFries, R. S., Jin, Y., and van Leeuwen, T. T..: Global fire emissions and the contribution of deforestation, savanna, forest, agricultural, and peat fires (19972009), Atmos. Chem. Phys., 10, 11707-11735, doi:10.5194/acp10-11707-2010, 2010.

Wang, H., Easter, R. C., Rasch, P. J., Wang, M., Liu, X., Ghan, S. J., Qian, Y., Yoon, J.-H., Ma, P.-L., and Vinoj, V.: Sensitivity of remote aerosol distributions to representation of cloud-aerosol interactions in a global climate model, Geosci. Model Dev., 6, 765-782, doi:10.5194/gmd-6-765-2013, 2013.

Wang, H., Rasch, P. J., Easter, R. C., Singh, B., Zhang, R., Ma, P. L., Qian, Y., and Beagley, N.: Using an explicit emission tagging method in global modeling of source-receptor relationships for black carbon in the Arctic: Variations, Sources and Transport pathways, J. Geophys. Res.-Atmos., 119, 12888-12909, doi:10.1002/2014JD022297, 2014.

Wang, M., Xu, B., Cao, J., Tie, X., Wang, H., Zhang, R., Qian, Y., Rasch, P. J., Zhao, S., Wu, G., Zhao, H., Joswiak, D. R., Li, J., and Xie, Y.: Carbonaceous aerosols recorded in a southeastern Tibetan glacier: analysis of temporal variations and model estimates of sources and radiative forcing, Atmos. Chem. Phys., 15, 1191-1204, doi:10.5194/acp-15-1191-2015, 2015.

Wang, Q., Jacob, D. J., Fisher, J. A., Mao, J., Leibensperger, E. M., Carouge, C. C., Le Sager, P., Kondo, Y., Jimenez, J. L., Cubison, M. J., and Doherty, S. J.: Sources of carbonaceous aerosols and deposited black carbon in the Arctic in winter-spring: implications for radiative forcing, Atmos. Chem. Phys., 11, $12453-$ 12473, doi:10.5194/acp-11-12453-2011, 2011.
Wang, X., Doherty, S. J., and Huang, J.: Black carbon and other light-absorbing impurities in snow across Northern China, J. Geophys. Res.-Atmos., 118, 1471-1492, doi:10.1029/2012JD018291, 2013.

Warren, S. G. and Wiscombe, W. J.: A model for the spectral albedo of snow, II: Snow containing atmospheric aerosols, J. Atmos. Sci., 37, 2734-2745, 1980.

Xu, B., Cao, J., Hansen, J., Yao, T., Joswiak, D. R., Wang, N., Wu, G., Wang, M., Zhao, H., Yang, W., Liu, X., and He, J.: Black soot and the survival of Tibetan glaciers, Proc. Natl. Acad. Sci. USA, 106, 22114-22118, 2009.

Ye, H., Zhang, R., Shi, J., Huang, J., Warren, S. G., and $\mathrm{Fu}, \mathrm{Q}$.: Black carbon in seasonal snow across northern Xinjiang in northwestern China, Environ. Res. Lett., 7, 044002, doi:10.1088/1748-9326/7/4/044002, 2012.

Yu, H., Remer, L., Chin, M., Bian, H., Tan, Q., Yuan, T., and Zhang, Y.: Aerosols from Overseas Rival Domestic Emissions over North America, Science, 337, 566-569, 2012.

Yu, H., Chin, M., West, J. J., Atherton, C. S., Bellouin, N., Bergmann, D., Bey, I., Bian, H., Diehl, T., Forberth, G., Hess, P., Schulz, M., Shindell, D., Takemura, T., and Tan, Q.: A multimodel assessment of the influence of regional anthropogenic emission reductions on aerosol direct radiative forcing and the role of intercontinental transport, J. Geophys. Res., 118, 700 720, doi:10.1029/2012JD018148, 2013.

Zhang, R., Hegg, D. A., Huang, J., and Fu, Q.: Source attribution of insoluble light-absorbing particles in seasonal snow across northern China, Atmos. Chem. Phys., 13, 6091-6099, doi:10.5194/acp-13-6091-2013, 2013.

Zhang, R., Wang, H., Qian, Y., Rasch, P. J., Easter, R. C., Ma, P.L., Singh, B., Huang, J., and Fu, Q.: Quantifying sources, transport, deposition and radiative forcing of black carbon over the Himalayas and Tibetan Plateau, Atmos. Chem. Phys., 15, 62056223, doi:10.5194/acp-15-6205-2015, 2015.

Zhao, C., Hu, Z., Qian, Y., Ruby Leung, L., Huang, J., Huang, L., Jin, J., Flanner, M. G., Zhang, R., Wang, H., Yan, H., Lu, Z., and Streets, D. G.: Simulating black carbon and dust and their radiative forcing in seasonal snow: a case study over North China with field campaign measurements, Atmos. Chem. Phys., 14, 1147511491, doi:10.5194/acp-14-11475-2014, 2014. 